\author{
BARBARA PRZYBYSZEWSKA-JARMIŃSKA \\ INSTYTUT SZTUKI, POLSKA AKADEMIA NAUK
}

\title{
INFORMACJE ZE ŹRÓDEŁ AUGUSTIAŃSKICH O ŻYCIU MUZYCZNYM W WARSZAWSKIM KOŚCIELE ŚW. MARCINA W XVII WIEKU ORAZ O DZIAŁAJĄCYCH W TYM CZASIE MUZYKACH KRÓLEWSKICH
}

\begin{abstract}
Kościół św. Marcina oo. augustianów w Warszawie od XVII w., kiedy warszawski Zamek Królewski stał się główną siedzibą kolejnych królów Polski, stanowił nie tylko miejsce dość intensywnego uprawiania muzyki przez samych zakonników i muzyków przez nich wynajmowanych, ale i występów kapeli królewskiej. W samym klasztorze zaś znajdowali mieszkanie muzycy królewscy, którzy należeli do zakonu św. Augustyna. Zachowane, pomimo ogromnych strat związanych z kasatą klasztoru po powstaniu styczniowym, rozproszone źródła związane z jego dziejami, jak również dokumenty prowincji polskiej oo. augustianów, nie tylko poświadczają działalność w kościele zakonnych kantorów, organistów i muzyków innych specjalności, a także fakt zatrudniania lub zapraszania muzyków z zewnątrz w celu uświetniania najważniejszych uroczystości kościelnych, ale też przynoszą nieznane informacje do biografii konkretnych muzyków należących w tym czasie do kapeli królewskiej. Główną bazę źródłową niniejszego artykułu stanowią rękopisy z XVII, a wyjątkowo XVIII i XIX w., przechowywane przede wszystkim w różnych zbiorach warszawskich: w Archiwum Archidiecezjalnym ${ }^{\mathrm{I}}$, Bibliotece Muzeum Warszawy ${ }^{2}$, Bibliotece Uniwersyteckiej³, Bibliotece Narodowej ${ }^{4}$ i Bibliotece Instytutu Badań Literackich
\end{abstract}

I Archiwum Archidiecezjalne w Warszawie, Zgromadzenia zakonne: OO Augustianie. W tym zespole zachowane są, jeżeli chodzi o wiek XVII, dwie rękopiśmienne księgi rachunkowe klasztoru św. Marcina: za lata I63I-37 (sygn. 7) i lata I68I-94 (sygn. 4I). Będą one dalej cytowane jako Wa Aug. 7 i Wa Aug. 4I.

2 Biblioteka Muzeum Warszawy, rps A/I/326r: Tabula censuum klasztoru św. Marcina w Warszawie (dalej Wmhw A/I/326I).

3 Biblioteka Uniwersytecka w Warszawie, Gabinet Rękopisów, rps 2I i rps 25 (dalej Wu 2I, Wu 25).

4 Biblioteka Narodowa, Oddział Rękopisów, rps akc. 6385: Liber provinciae Poloniar[um] et Mag[ni] Duc[atus] Lith[uaniae] etc. Ord[inis] FF. Eremitarum S.P. Augustini, in quo capitula, ordinationes, indulta, brevia, decreta SS. PP. atque generalia, provincialia promotionesque et caetera publica continentur ab anno Domini I6I6 (dalej Wn akc. 6385). 
PAN', a także w Archiwum Narodowym w Krakowie (przy ul. Siennej) ${ }^{6}$, do którego w latach pięćdziesiątych XX w. trafiła duża część archiwaliów rozwiązanego wówczas augustiańskiego krakowskiego klasztoru św. Katarzyny Aleksandryjskiej. Informacje pochodzące z tych źródeł uzupełniane są o wiadomości zaczerpnięte z innych siedemnastowiecznych rękopisów znajdujących się w PAN Bibliotece Kórnickiej ${ }^{8}$, Archiwum Archidiecezjalnym w Poznaniu ${ }^{9}$, Archiwum Archidiecezjalnym w Warszawie ${ }^{\mathrm{IO}}$, Archivio Segreto Vaticano ${ }^{\text {II }}$ i Biblioteca Apostolica Vaticana ${ }^{\text {I2 }}$, a także z dokonanych w XIX i XX w. wypisów i opracowań źródeł już nieistniejących, zachowanych w Bibliotece Jagiellońskiej ${ }^{13}$ i Bibliotece Naukowej PAU-PAN w Krakowie ${ }^{\mathrm{I} 4}$, jak również

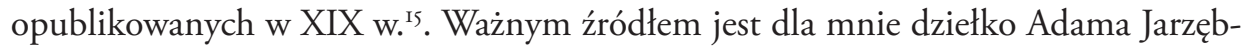
skiego Gościniec abo Krotkie opisanie Warszawy (Warszawa: Piotr Elert, 1643) ${ }^{16}$.

5 Biblioteka Instytutu Badań Literackich PAN, rps 227: Ciekawości różne zebrane dla wiadomości mtodszym, tak śmierci pobożnej Braci Augustinianów, jako też dawniejszego wieku zastużonych godniejszych - Ojców, tudzież pomnożonych fundacyj po wprowadzeniu onych do Polski, krótko zebrane przez Xiędza Alipiego Niedzielskiego Augustynianina S. T.D. i tejże professora $w$ Warszawie roku I8I3, źródło określane w literaturze przedmiotu jako „Kronika Niedzielskiego”, tu cytowane jako Wibl 227.

6 Archiwum Narodowe w Krakowie (Oddział Sienna), Archiwum OO Augustianów: rps 29/501/23: Fulgenty Dryjacki, Horologium chronologiae climacteriae (dalej Kan 29/50I/23), pisane u schyłku XVII w. (w literaturze określane jako „Kronika Dryjackiego”, co jest mylące, ponieważ oprócz tej łacińskojęzycznej pracy i jej wtórnej, dziewiętnastowiecznej kopii (rps 29/50I/24) w tym samym archiwum przechowywany jest rps 29/50I/2I zawierający polskojęzyczny tekst nieukończonego dzieła noszącego tytuł Kronika Braci Zakonu Eremitów Augustyna S. [...] przez X. Fulgentego Dryjackiego tegoż zakonu niegodnego brata $i$ kaptana, $w$ Krakowie 1669); rps 29/50I/38: zawierający m.in. akta kapituł prowincjalnych z XVII w.; rps 29/50I/7I: Liber professionum Fratrum Eremitarum [... ] ab anno I63I (dalej: Kan 29/50I/7I); rps 29/501/87: Anniversarium quotidianum pro animabus patrum, fratrum, sor[orum] Ordinis Eremitarum S.P. Augustini Provinciae Poloniae [...] I760[-I894] (dalej: Kan 29/50I/87); rps 29/50I/88: analogiczne Anniversarium z wpisami zmartych w l. I346-1950 (dalej: Kan 29/50I/88).

7 Na temat dziejów klasztoru i kolekcji zob. „Wstęp” w: Wacław Kolak, Katalog Archiwum OO Augustianów I299-I950, Kraków I996, s. 9-43, zwłaszcza s. 3I-37.

8 Polska Akademia Nauk Biblioteka Kórnicka, rps 292 nr 39 (dalej KÓ 292 nr 39).

9 Archiwum Archidiecezjalne w Poznaniu, Acta Episcopalia XXXIV i XXXVI (dalej Pa AE XXXIV i Pa AE XXXVI).

Io Archiwum Archidiecezjalne w Warszawie, Parafia św. Jana Chrzciciela w Warszawie: sygn. IO2: Księga chrztów I602-I5; sygn. I06: Księga chrztów I640-49; sygn. I07: Księga chrztów I649-59; sygn. IO8: Księga chrztów 1659-68; sygn. I09: Księga chrztów I669-78 i sygn. 304: Księga zaślubionych I673-89 (dalej Wa Par. św. Jana Io2, Wa Par. św. Jana I06, Wa Par. św. Jana I07, Wa Par. św. Jana I08, Wa Par. św. Jana Io9, Wa Par. św. Jana 304).

II Archivio Segreto Vaticano, Segreteria dei Brevi (Secretaria Brevium), Registra Brevium, vol. I502 (dalej Rasv, Sec. Brev., Reg., vol. I502).

I2 Biblioteca Apostolica Vaticana, Archivio del Capitolo di S. Pietro, Armadi I5, Decreti I2 (dalej Rbav, Arch. Cap. di S. Pietro, Armadi 15, Decreti I2).

I3 Biblioteka Jagiellońska w Krakowie, rps 6948 II: Materiaty i notatki ks. Wtadystawa Knapińskiego (dalej Kj 6948 II).

I4 Biblioteka Naukowa PAU-PAN w Krakowie, rps 2357: ks. Jan Ambroży Wadowski, Kościoty lubelskie (dalej Kp 2357). Za zwrócenie mi uwagi na ten rękopis serdecznie dziękuję Pani prof. Irenie Rolskiej z Katolickiego Uniwersytetu Lubelskiego.

I5 Józef Łukaszewicz, Krótki opis historyczny kościotów parochialnych [...] Diecezji Poznańskiej, t. 3, Poznań I863.

I6 Również jego dwudziestowieczne wydania: Adama Jarzębskiego Gościniec abo Opisanie Warszawy I643 r., wyd. Władysław Korotyński, Warszawa 1909; Adam Jarzębski, Gościniec abo Krotkie opisanie Warszawy, opr. i wstępem opatrzył Władysław Tomkiewicz, Warszawa 1974. 
Muzyka w kościele św. Marcina nie była dotąd przedmiotem systematycznych badań muzykologów. Obecne w pracach historycznych i z zakresu historii muzyki wiadomości na ten temat są nieliczne i wyrywkowe. Na ugruntowanie się nie w pełni prawdziwej opinii o muzyce w tym kościele w XVII w. znaczny wpływ wywarł Julian Bartoszewicz swoją książką o kościołach warszawskich ${ }^{17}$, a następnie autor podstawowej monograficznej pracy o augustianach w Polsce, o. Grzegorz Uth ${ }^{18}$. Informacje z tych prac czerpali także muzykolodzy, starając się jednak, jak Hieronim Feicht, unikać powielania dezinformacji, a dodawać wiadomości pochodzące z innych źródeł' ${ }^{19}$.

Uprawianie muzyki w warszawskim klasztorze oo. Augustianów (założonym w XIV stuleciu ${ }^{20}$ ) nie zaczęło się w wieku XVII. Jest to oczywiste, biorąc pod uwagę regułę zakonu św. Augustyna, co najmniej jeżeli chodzi o śpiew chorałowy zakonników. Muzyka, także „figuralna” (wokalna i wokalno-instrumentalna) oraz organowa, rozbrzmiewała w klasztorze również w ciagu wieków XVIII ${ }^{21}$ i XIX do kasaty po powstaniu styczniowym w I864 $\mathrm{r}^{22}$. Ograniczenie zakresu chronologicznego artykułu wynika z faktu, że to w XVII stuleciu życie muzyczne w kościele św. Marcina w sposób znaczący wiązało się z działalnością w Warszawie szczególnie mnie interesujących muzyków królewskich, którym poświęcam kolejne paragrafy, po przedstawieniu znanych mi informacji z tego czasu o organach, organistach, kantorach i zakonnych muzykach oraz obecności muzyki polifonicznej w kościele i klasztorze warszawskich augustianów w badanym okresie.

Najwcześniejsze chronologicznie wiadomości, dotyczące muzyki w kościele św. Marcina w XVII w. pochodzą z Horologium Fulgentego Dryjackiego i odnoszą się do sprawionych tam w I6ı́ r. za sprawą eksprowincjała Jakuba Mojskiego wielkich organów, na

I7 Julian Bartoszewicz, Kościoty warszawskie rzymsko-katolickie opisane pod względem historycznym, Warszawa I855, s. 7I.

I8 Grzegorz Uth, Szkic historyczno-biograficzny zakonu augustiańskiego w Polsce, Kraków I930, zwłaszcza s. 26I.

I9 Hieronim Feicht, „Muzyka w okresie polskiego baroku”, w: Z dziejów polskiej kultury muzycznej, t. I, red. Zygmunt M. Szweykowski, Kraków 1958, s. I66 (przedruk w: Hieronim Feicht, Studia nad muzyka polskiego renesansu i baroku, red. Zespół, Kraków I980, s. IOI), a następnie m.in. Barbara Przybyszewska-Jarmińska, Historia muzyki polskiej, t. 3, Barok, cz. I, I595-I696, Warszawa 2006, s. I05.

20 Na prośbę księcia mazowieckiego Ziemowita III St. aktem z 5 VII I356 r. papież Innocenty VI zezwolił na sprowadzenie augustianów na Mazowsze, gdzie jeszcze w tym samym roku powstał klasztor w Warszawie i Rawie, a dwa lata później w Ciechanowie, zob.: Janina Kowalczyk, „Augustianie-Eremici”, III: „W Polsce”, w: Encyklopedia Katolicka, t. I, red. Feliks Gryglewicz, Romuald Łukaszyk, Zygmunt Sułowski, Lublin i985, kol. I076.

2I Z tego stulecia pochodzą świadczące o jej rozmachu klasztorne inwentarze instrumentów (zob. Wu 25, np. k. 7-8).

22 Na temat organów w XVIII i XIX w. zob.: Jerzy Gołos, Warszawskie organy: historia i zabytki, t. 2, Katalog aktualny, katalog historyczny, Warszawa 2003, s. 236-237. Do podanych tam faktów można dodać, że w „Kronice Niedzielskiego” znajduje się informacja o reperacji organów dokonanej w I8I3 r. przez organmistrza Jakuba Kościeniewicza z Wilna (Wibl 227, k. II4v). 
których jako pierwszy grał Izajasz z Bochni, wówczas przeor klasztoru²3. Z tej wzmianki, na podstawie której od czasów ksiązi Utha ${ }^{24}$ podaje się w publikacjach o różnym charakterze, że organy pojawiły się w kościele św. Marcina dopiero w I6ı̀ r., a pierwszym organistą był Izajasz z Bochni, takie konstatacje nie wynikają. Jak słusznie zauważył Jerzy Gołos, organy, zapewne małe, musiały być u warszawskich augustianów co najmniej od XVI w., skoro działał tam i zmarł w 1585 r. organista Walenty ${ }^{25}$ (wśród zmarłych augustianów, za których modlili się i nadal modlą ich współbracia 27 stycznia, jest „Venerabilis Pater Valentinus organarius" zmarły w $1585 \mathrm{r}^{26}$ ). Co do Izajasza z Bochni, zanim przybył do Warszawy, należał jako organista do społeczności klasztoru oo. Augustianów św. Katarzyny Aleksandryjskiej w Krakowie, co potwierdza jego własnoręczny podpis na dokumencie o charakterze prawno-majątkowym z 8 X I6I4 r. ${ }^{27}$. Nie wiadomo dokładnie, kiedy znalazł się w klasztorze warszawskim, ale był tam na pewno co najmniej od I6I8 r., w czerwcu tego roku został bowiem jego przeorem ${ }^{28}$, wybranym na tę funkcję także na kapitułach w I619 i I622 r. ${ }^{29}$. Odbywało się to wbrew obowiązującej zasadzie kadencyjności $^{30}$, co spowodowało interwencję generała augustianów w Rzymie Fulgentiusa a Monte Georgio w piśmie do prowincjała Andreasa Simonidesa z 2 VII I 622 r. oraz w liście do augustianów konwentu warszawskiego z 29 października tegoż roku, w których stanowczo przeciwstawił się on takiej praktyce ${ }^{31}$. Być może w związku z tym Izajasz z Bochni opuścił na jakiś czas Warszawę. W każdym razie na kapitule z i625 r. został wybrany przeorem w klasztorze augustiańskim w Wieluniu ${ }^{32}$. Potem, od I628 r., był kaznodzieją w Radomyślu ${ }^{33}$, aż na posiedzeniu kapituły w I63I r. został wybrany na prowincjała ${ }^{34}$, przy czym także

23 Kan 29/50I/23, s. II2: „In templo Varsoviensi [Jacobus Moiscius - B.P.-J.] organum magnum comparavit ad S. Martinum, cuius erat primus organarius anno I6I9 Pater Izaias Bochnensis, prior eiusdem conventus". Edycji tego i następnych zamieszczonych w artykule łacińskich, jak również starowłoskich tekstów dokonał dr Leszek Jarmiński, za co jestem mu bardzo wdzięczna. Dziękuję mu również za szereg wskazówek bibliograficznych.

24 G. Uth, Szkic historyczno-biograficzny, s. 249-250.

25 J. Gołos, Warszawskie organy, s. 236.

26 Kan 29/5or/87, s. 33; Wspomnienie zmartych Polskiej Prowincji Zakonu Św. Augustyna od roku 1346. Przepisat z oryginatu (lata 1346-I950) [z Kan 29/50I/88 - B.P.-J.] Tomasz Ściężor w czerwcu 2010 r., druk wewnętrzny, w klasztorze św. Katarzyny Aleksandryjskiej w Krakowie, za którego udostępnienie serdecznie dziękuję proboszczowi, o. Markowi Krzysztofowi Donajowi OSA, s. 29. (Wiadomość o zmarłym 27 I I585 r. organiście Walentym podana także w: Jerzy Mizgalski, „Organiści i organmistrze polscy”, Prace Naukowe Instytutu Muzykologii UW I (196I), s. 86, i za tym m.in. w: Stownik muzyków polskich, red. Józef Chomiński, t. 2, Kraków 1967, s. 95 (tu z błędnym rokiem - I583); J. Gołos, Warszawskie organy, s. 236).

27 Kan 29/50I/38, s. I5.

28 Kj 6948 II, k. 320: wypis ks. Władysława Knapińskiego z nieistniejących już akt Archiwum Konsystorza Warszawskiego (XII.38).

29 Wn akc. 6385, k. 34, 55v.

30 Można było sprawować funkcję przeora w danym klasztorze tylko przez jedną kadencję i ewentualnie ponownie po co najmniej trzyletniej przerwie.

3I Wn akc. 6385, k. 62v, $58 \mathrm{v}-59$.

32 Ibid., k. $65 \mathrm{v}$.

33 Ibid., k. $72 \mathrm{v}$.

34 Ibid., k. 8o. 
pełniąc tę funkcję, powracał do warszawskiego klasztoru - w I632 r. przeprowadził w nim wizytację̨5. Jako przeor wrócił do Warszawy na l. $1637-40^{36} \mathrm{i}$ zapewne pozostawał tam do roku $1643^{37}$. W klasztorze św. Marcina przebywał także na przełomie lat czterdziestych i pięćdziesiątych ${ }^{38}$. W I655 r. został przeorem we Lwowie ${ }^{39}$, gdzie zmarł 7 I I657 r. ${ }^{40}$. Czy podczas pobytów w warszawskim klasztorze w latach trzydziestych i następnych grywał na organach, nie jest wykluczone. $Z$ pewnością nie pełnił jednak wówczas obowiązków organisty. Odnalezione źródła nie informują wprawdzie, kto był organistą od I625 r., kiedy Izajasz przeniósł się do Wielunia, ale wzmiankują zatrudnionego w klasztorze w I632 r. bliżej nieznanego organistę świeckiego (wypłaty potwierdzone są w księdze rachunkowej za rok I632, a także z okresu od stycznia do października I633 r. $)^{4 \mathrm{t}}$.

W źródłach zl. 1634-43 i 1649-52 występuje jako organista w kościele św. Marcina Wilhelm Ruczkowski (notowany najczęściej jako „Guilhelmus” lub „Guilelmus”) ${ }^{42}$, w roku I634 i 1635 jako brat ${ }^{43}$, później, od I637 r., ojciec („V.P. Guillelmus organarius”44). W I652 r. akta kapituły prowincji informują, że był chory („V.P. Guilhelmus organarius infirmus") ${ }^{45}$. Zmarł w Warszawie I4 VI 1655 r.46. Można przypuszczać, że przed śmiercią zdążył wykształcić swojego następcę, w aktach kapituły prowincjalnej z I649 r. wśród zakonników warszawskiego klasztoru znajdował się bowiem, obok Wilhelma Ruczkowskiego, „V.P. Nicolaus organarius per studio”47. Jest więcej niż prawdopodobne, że był to Mikołaj Sieracki, mający stopień lektora świętej teologii, który zmarł w Warszawie 25 XII I664 r., a w Annuarium quotidianum został odnotowany jako „V.P. Nicolaus Sieracki S.T.L., musicus”48.

Jeszcze za życia Mikołaja Sierackiego, w roku I66I, notowany jest w znalezionych źródłach po raz pierwszy jako organista w klasztorze św. Marcina Marian Chebdowski, wówczas brat zakonny, subdiakon ${ }^{49}$. Zapisywany w łacińskojęzycznych aktach kapituł najczęściej jako „Marianus organarius”, „Marianus Hebdovic, organarius” lub „Marianus Hebdovius, organarius”, wyjątkowo jako „Maranius Chebdovius,

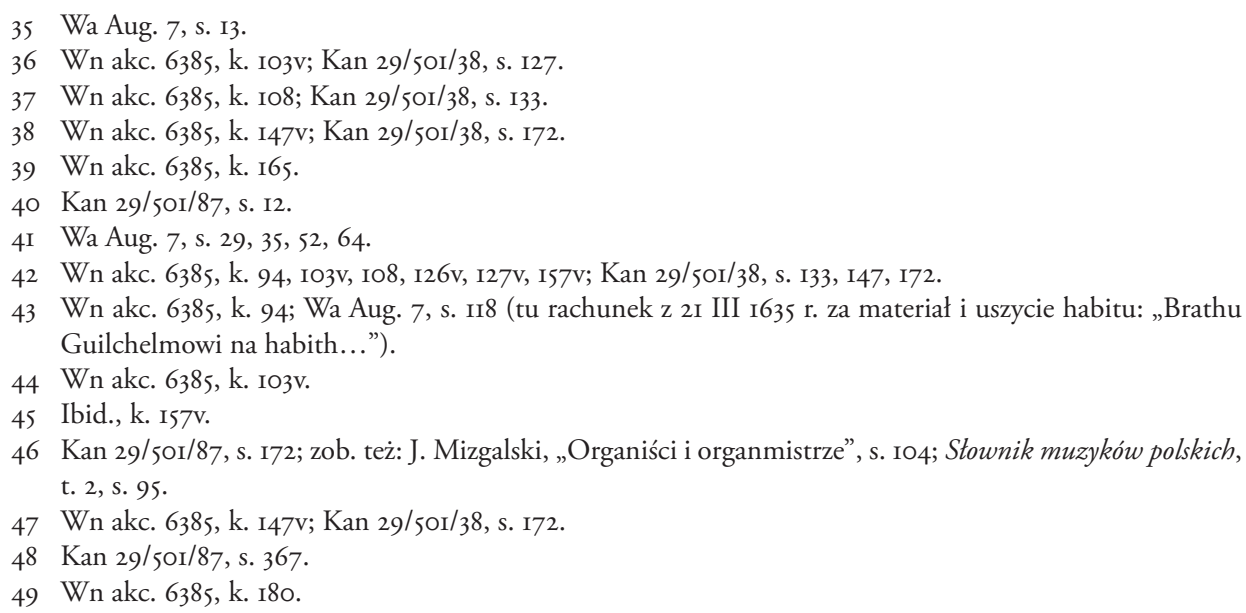


organarius" "50, sam, w zachowanej księdze rachunków klasztoru św. Marcina w latach osiemdziesiątych i początkach dziewięćdziesiątych XVII w., podpisywał się jako „Fr. Marianus Chebdowius” 51 lub „Fr. Marianus Chebdowski” ${ }_{2}$. W rachunkach tych są dość liczne wzmianki o ks. Chebdowskim i wydatkach z nim związanych. Wynika z nich jednocześnie, że zdarzało się, iż przez jakiś czas był on nieobecny w klasztorze. W takich sytuacjach zatrudniano organistę, który go zastępował ${ }^{53}$. W czasie działalności Chebdowskiego w klasztorze warszawskim doszło do remontu organów, z pewnością już nie tych, na których grywał Izajasz z Bochni, ale nowych, zbudowanych zapewne po „potopie” szwedzkim. Nowy instrument musiał być większy i posiadał klawiaturę pedałową, bowiem była ona reperowana, w związku z czym w rachunkach klasztoru zanotowano 22 III I682 r. wydatek: „Orgamistrzowi od naprawy pedalnych klawiszów fl. 3 "54. Instrument wymagał najwyraźniej dalszych remontów, skoro warszawscy zakonnicy ubiegali się o środki na ten cel podczas kapituły prowincjalnej w 1688 roku. Z akt kapituły wynika jednak, że musieli sobie radzić sami:

Ażeby organy kościoła warszawskiego mogły być reperowane, Czcigodne Definitorium zarządza, że z dochodów muzyków za prywatne msze żałobne, litanie i inne z każdego florena należy brać trzy grosze wkładane do wyznaczonej na to puszki, aby były naprawiane bez szkody klasztoruss.

Na kapitule prowincjalnej w I679 r. Chebdowski oraz Hieronim Bobowski otrzymali polecenie, aby zdolnych młodszych braci uczyli grać na organach ${ }^{56}$. Bobowski, choć jeszcze studiował, był już w tym czasie organistą w klasztorze krakowskim ${ }^{57}$.

50 Ibid., k. 379

5I Wa Aug. 4I, bardzo liczne podpisy, m.in. k. 38, [40], 4IV, 43, 45, 47, 52v, 54, 55v, 56v, 58, 59, 6Iv, 63, 64, 65, 66v, 68, 69v, 7I, 72v, 74, 75, 76v, 78, 79v, 8Iv, 83, 84v, 86, 88, 90, 9Iv, 93, 94v, 96v, 98, 99v, IOI, IO2v, I24v, I26, I27v, I29, I30, I3IV, I38v, I39v, I4I, I42v, I44, I45V, I47, I49, I5I, I53, I54V, I56, I58v, I65V, I67v, I69v, I7I, I79V, I8I, I86V, I9O, 2IO, 2I2V, 2I4, 2I7, 2I8v, 220, 220V, 228v, 229V, 230, $23 \mathrm{I}$.

52 Ibid., k. 45 .

53 Na przykład, kiedy I4 VII I689 r. ks. Chebdowski wyjechał do Szydłowca („X. Marianowi organiście na wozy kowane i żelazo do Szydłowca fl. Ioo” (Wa Aug. 4I, k. I63)), zapłacono jego zastępcy, informując w rachunkach 28 VII I689 r.: „Poczesna organisty, który in abs[enti]a naszego grawał - fl. 3” (Wa Aug. 4I, k. I63v).

54 Wa Aug. 4I, k. 25. O reperacji tej wzmiankuje Jerzy Gołos, nie podając szczegółowo źródła informacji. Według opinii tego autora do budowy nowych organów po „potopie” doszło w latach siedemdziesiątych XVII w., zob.: J. Gołos, Warszawskie organy, s. 236.

55 Wn akc. 6385, k. 346v: „Ut organa ecclesiae Varsoviensis reparari possint, decern[e]t Venerabile Deffinitorium, quod ex perceptis musicorum pro votivis missis requialibus, littaniis et aliis a singulo floreno recipiantur grossi tres in carbonam ad hoc deputandam mittendi, ut sine damno conventus reparentur". Informacja na ten temat także w: Zofia Kratochwil, „Augustianie w Warszawie. Kościół i klasztor św. Marcina (I356-I864)”, Warszawskie Studia Teologiczne 7 (1994), s. 205, z odniesieniem do tego samego źródła i dawnej foliacji k. 559v.

56 Kan 29/501/38, s. 99: „Venerabilibus Patribus Mariano Hebdovio et Hieronymo Bobovio organariis iniungitur et praecipi[tur], ut iuniores fr[atr] es capaces pulsare organa doceant”. Niemal identyczny tekst w: Wn akc. 6385 , k. 216v.

57 Śluby złożył 7 VI I673 r. w Krakowie (Kan 29/50I/7I, s. 26), w aktach kapituł z 1. I676 i I679 jest wymieniony wśród zakonników klasztoru krakowskiego jako „organarius pro studio” (Kan 29/50I/38, s. 9I; Kan 29/50I/4I, s. II). 
W I68I r. przez co najmniej kilka miesięcy przebywał w Warszawie ${ }^{58}$ jako kantor ${ }^{59}$. W późniejszych latach był m.in. przeorem w Wilnie, gdzie zmarł I5 VI I694 r. ${ }^{60}$. Co do Chebdowskiego, zmarł zapewne w Warszawie, ale nie, jak zapisano w Annuarium quotidianum, 29 VII 1690 r. $^{61}$. Jest on wymieniony wśród zakonników klasztoru w Warszawie w aktach kapituły z roku $\mathrm{I}_{69 \mathrm{I}^{62}}$, a jego własnoręczne podpisy zatwierdzające miesięczne zestawienia rachunków klasztoru były jeszcze składane w drugiej połowie I692 r., ostatni we wrześniu tego roku, przy czym podpisujący określał siebie jako zakrystiana: „Fr. Marianus Chebdowius, sacrista”63.

Z końcowych lat XVII w. nie udało się znaleźć nazwiska organisty w klasztorze św. Marcina. Być może przez jakiś czas zakonnicy zatrudniali organistów spoza społeczności klasztornej (w źródłach łacińskich określanej jako familia). Na przykład w maju I693 r. organistą był jakiś Krzysiek, jak informuje trywialny zapis w rachunkach dnia I9 tego miesiąca i roku: „Krzyśkowi organiście na boty - zł 6”64. We wrześniu w 1693 r. wymieniony jest w tych rachunkach „X. Organista” ${ }^{65}$. Nic więcej o nim nie wiadomo.

W swojej książce o kościołach warszawskich Julian Bartoszewicz, rzekomo cytując Gościniec Jarzębskiego, a w istocie jego zmieniony przez Juliana Ursyna Niemcewicza prozatorski tekst ${ }^{66}$, napisał o muzyce $\mathrm{w}$ kościele warszawskich augustianów następujące słowa: „Ojcowie ci utrzymują liczną kapelę, tu się muzykowie chowają i mnie też tu leżeć przyjdzie” oraz - już od siebie - „muzyka musiała kosztować ich dużo" ${ }^{67}$. Ta opinia o działalności w kościele św. Marcina w czasach Jarzębskiego kapeli powtarzana jest w następnych pracach ${ }^{68}$, a niektórzy autorzy twierdzą nawet, że kapela wokalno-instrumentalna powstała już w XVI w., jako pierwszy taki zespół w kościołach warszawskich ${ }^{69}$.

Opinia Bartoszewicza, przejęta przez Utha i następnych autorów, opiera się z pewnością na niewłaściwej interpretacji przez Niemcewicza słów Adama Jarzębskiego, który w swoim Gościńcu, opisując kościół św. Marcina, napisał m.in.:

\footnotetext{
58 Wa Aug. 4I, liczne jego podpisy: k. 5V, 6v, 7, 8, 9V, IIV, I3V, I5V, I7V, I8v, $20 \mathrm{v}$.

59 Ibid., k. II: 2I VII I68I r. odnotowano wydatek z kasy klasztoru: „V.P. Hieronymo Bobowski, cantori. Na potrzeby w chorobie fl. o,I5".

60 Wan $29 / 501 / 87$, s. 173 .

6I Kan 29/50I/87, s. 218. Tak też w: Wspomnienie zmartych Polskiej Prowincji Zakonu św. Augustyna, s. 224.

62 Wn akc. 6385, k. 379.

63 Wa Aug. 4I, k. 23I.

64 Ibid., k. 238.

65 Ibid., k. $245 \mathrm{v}$.

66 „Opisanie Warszawy jaką była w roku I643”, w: Julian Ursyn Niemcewicz, Zbiór pamiętników o dawnej Polszcze, t. 3, Warszawa I822, s. 407-448, tu s. 4I5.

67 J. Bartoszewicz, Kościoty warszawskie, s. 7I.

68 Np.: G. Uth, Szkic historyczno-biograficzny, s. 26I.

69 Z. Kratochwil, „Augustianie w Warszawie”, s. 205.
} 


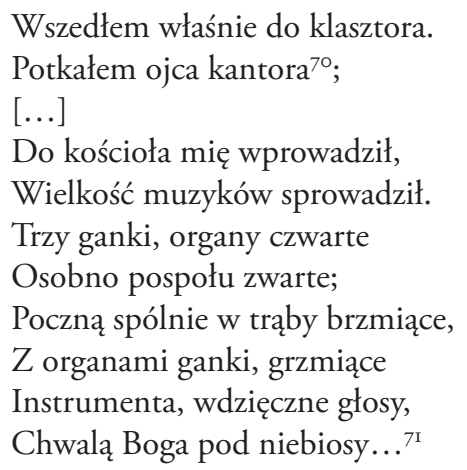

Niemcewicz, a za nim Bartoszewicz, uznał, że słowa „wielkość muzyków sprowadził" znaczą, iż w klasztorze było wielu muzyków, czyli była kapela. Nie potwierdzają takiej interpretacji zachowane źródła. Trzeba przyjąć, że Jarzębski chciał jedynie powiedzieć, że do kościoła św. Marcina przychodzi i gra oraz śpiewa wielu muzyków (ściśle, ale chyba raczej z uwagi na zabiegi związane z rymowaniem tekstu, napisane jest, że muzyków tych sprowadził kantor). Tego wprawdzie Jarzębski nie napisał, ale można dodać, że w szczególności byli to w jego czasach muzycy królewscy.

Niestety, z okresu panowania Zygmunta III i początków rządów Władysława IV źródłowego potwierdzenia udziału kapeli królewskiej w liturgii sprawowanej w kościele św. Marcina nie udało się znaleźć, są jednak świadectwa kontaktów poszczególnych muzyków z klasztorem, w tym źródła potwierdzające, że niektórzy z nich tam mieszkali i działali, o czym niżej. Informacje pochodzące z różnych źródeł wytworzonych w XVII w. już po ukazaniu się Gościńca pozwalają twierdzić, że w istocie kapele kolejnych królów Polski uświetniały uroczystości kościelne u warszawskich augustianów. Wiadomo, że muzycy królewscy gromadzili się w kościele z okazji nabożeństwa w dniu św. Cecylii, na pewno od 1646 r., kiedy potwierdzona jest działalność w kościele św. Marcina bractwa św. Cecylii ${ }^{72}$, ale niewykluczone, że istniejącego już wcześniej (o okolicznościach założenia bractwa niżej, w paragrafie „Adeodato Barochius i Alfonso Selvatici”). Gościnnie śpiewały i grały w warszawskim kościele augustiańskim także inne kapele, a zdarzało się, już w pierwszej połowie XVII w., że zakonnicy opłacali okolicznościowo zatrudnianych muzyków ${ }^{73}$. W odniesieniu do

$70 \mathrm{Z}$ wszelkim prawdopodobieństwem był to o. Ambroży Gruzelowicz, „superior et cantor”, zob.: Kan 29/501/38, s. I47.

$7 \mathrm{I}$ A. Jarzębski, Gościniec, wyd. W. Tomkiewicz, s. 93-94.

72 Pisze o tym Fulgenty Dryjacki w Horologium (Kan 29/50I/23, s. I4I) i bardziej szczegółowo, z odniesieniem się do „dokumentu rzymskiego” w tej sprawie, Alipi Niedzielski (Wibl 227, k. I79).

73 Tak zapewne należy interpretować informację z akt sądowych o sumie wydanej na muzyków śpiewających Requiem podczas pogrzebu Stanisława Zatorskiego, rajcy miasta Kazimierz (obecnie Kazimierza w Krakowie), który zatrzymał się w klasztorze św. Marcina, nie uprzedzając, że jest zakaźnie chory, i zmarł. Augustianie procesowali się z jego spadkobiercami o zwrot pieniędzy za poniesione straty i koszty, zob. Wu 2I, k. I97v. 
ostatnich dekad stulecia można mówić o zaczątkach kapeli kościoła św. Marcina. W zachowanych źródłach widoczna jest bowiem następująca w ciągu wieku zmiana, dotycząca stosowanych w odniesieniu do zakonników związanych z muzyką określeń ich funkcji. W pierwszej połowie XVII w. spotykamy w źródłach zakonników - organistów i kantorów, w drugiej zaś również takich, których nazywano muzykami, wyjątkowo z podaniem specjalności. Z uwagi na niewielką liczbę zakonników-muzyków w warszawskim klasztorze w tym czasie, przy różnych okazjach musieli oni być „wspomagani” przez dodatkowych, wynajmowanych muzyków. Taki zespół można by nazwać kapelą, nawet jeżeli zwoływana ona była ad hoc i nie miała stałego składu.

Kantorzy byli w klasztorze niezbędni do prowadzenia zgodnych z regułą śpiewów liturgicznych, w tym liturgii godzin, oraz uczenia śpiewu młodych ojców i braci. Chodziło o wykonywanie w chórze unisono śpiewów chorałowych, podczas gdy śpiew „figuralny” był dopuszczany, jak informują dekrety sporządzone po wizytacji z I6I9 r., jedynie z okazji szczególnie uroczystych ${ }^{74}$. Najwyraźniej z umiejętnościami śpiewu w różnych klasztorach prowincji polskiej nie było dobrze, w każdym razie w trudnych czasach drugiej połowy XVII stulecia, skoro na kapitule w i679 r. polecono kantorom, aby w klasztorach, w których to było możliwe, uczyli innych braci śpiewać 75 . Wydaje się, że to zalecenie nie przyniosło w klasztorze warszawskim pożądanych skutków, jeżeli po niemal dziesięciu latach, w I688 r., wizytator generalny o. Dominik Grabiński zwrócił uwagę, że tamtejsi zakonnicy zaniedbują śpiew chorałowy i zalecił prowadzenie trzy razy w tygodniu lekcji śpiewu ${ }^{76}$.

W wykorzystywanych źródłach kantorami w kościele św. Marcina określani byli w XVII w. następujący zakonnicy (w porządku chronologicznym): „Fr. Andreas diaconus cantor et pro studio” w 1628 r. ${ }^{77}$, „Andreas Jaslav, cantor” w I640 r. ${ }^{78}$, „V.P. Ambrosius Gruzelowicz, superior et cantor” w I643 r..$^{79}$, „V.P. Dominicus cantor” w 1655 r. ${ }^{80}$, "V.P. Marianus Hebdovius [Chebdowski - B.P.-J.], organarius et cantor" w I679 r. ${ }^{8 \mathrm{I}}$, V.P. Hieronim Bobowski w I68I r. ${ }^{82}$, „V.P. Bonawentura Krawarski, cantor” w 1685 r. $^{83}$, „cantor V.P. Chrysostomus Truszkowski” w I69I r. ${ }^{84}$ i „V.P. Esaias Pawlikowicz [?],

74 Wn akc. 6385, k. 32.

75 Kan 29/50I/38, s. 99: „Patres cantores, in quibus fieri potest conventibus, doceant alios fratres cantare”.

76 Wn akc. 6385, k. 362v, informacja także w: Z. Kratochwil, „Augustianie w Warszawie”, s. 204, z odniesieniem do tego samego źródła i dawnej foliacji (k. 566v); autorka pisze jednak nie o śpiewie chorałowym, ale chóralnym.

77 Wn akc. 6385 , k. 7 Iv.

78 J. Łukaszewicz, Krótki opis historyczny, s. 92.

79 Kan 29/50I/38, s. I47.

8 o Wn akc. 6385, k. I64v.

8I Kan 29/5OI/38, s. IO2.

82 Wa Aug. 4I, k. II.

83 Wn akc. 6385 , k. 301 .

84 Ibid., k. 379 . 
cantor" w 1699 r. ${ }^{85}$. Niektórzy z wymienionych byli też organistami (zob. wyżej) lub byli nazywani muzykami, np. Bonawentura Krawarski w aktach kapituł z 1. I679 i $1682^{86}$ (wydaje się, że w istocie działalność Krawarskiego nie ograniczała się do wykonywania obowiązków kantora; z rachunków klasztoru św. Marcina wiadomo, że był śpiewakiem-dyszkantystą, a zajmował się także instrumentami, na przykład zakupem skrzypiec, oraz goszczeniem i ewentualnie opłacaniem zatrudnianych okazjonalnie muzyków ${ }^{87}$ ). Inni zakonnicy, określani w familii warszawskiej jako muzycy, byli kantorami w innych klasztorach, jak Andreas Chrzanowski, wymieniony na kapitule w i676 r. w klasztorze św. Marcina bez wskazania funkcji czy specjalności i ze zniekształconym nazwiskiem: „V.P. Andreas Krzanowski”88, a w roku I682 jako „V.P. Andreas Chrzanowski, musicus”89, w I688 r. był w klasztorze św. Katarzyny kantorem („V.P. Andreas Chrzanowski, cantor"90). Zmarł 3I I I689 r. w Krakowie ${ }^{91}$.

Zapisywanie w rachunkach w latach osiemdziesiątych i dziewięćdziesiątych XVII w. wydatków na skrzypce i struny do skrzypiec świadczy o wykorzystywaniu instrumentów przez samych zakonników-muzyków lub może studiujących braci, albo też o zaopatrywaniu przez klasztor muzyków przychodzących z zewnątrz, którzy wspomagali zakonników w zapewnianiu oprawy muzycznej uroczystościom kościelnym ${ }^{92}$. Podobnie mogły być wykorzystywane wzmiankowane w rachunkach w sposób bardzo ogólny materiały nutowe (chodzi o informacje o oprawianiu partesów czy zakupie papieru przeznaczonego do zapisywania nut) ${ }^{93}$. Rachunki te zdają się świadczyć, że pewna liczba muzyków była (bywała?) zatrudniana nie tylko okazjonalnie, ale i w sposób bardziej stały ${ }^{94}$, oraz potwierdzają opłacanie trębaczy, którzy w określone święta grali z kościelnej wieży95. Te cenne źródła, niestety obejmujące tylko kilka-

85 Wn akc. 6385, k. 4 III.

86 Kan 29/50I/38, s. IO2; Wn akc. 6385, k. 222v, 226.

87 Wa Aug. 4I, k. 139, 199, 210, 210v.

88 Kan $29 / 501 / 38$, s. 90.

89 Wn akc. 6385, k. 222v, 226.

90 Ibid., k. $347 \mathrm{v}$.

9I Kan $29 / 501 / 87$, s. 37 .

92 Np. Wa Aug. 4I, k. 85v: II VI I685 r.: „Za traktament dla muzyków, którzy przez [Zielone] Świątki pomagali zł I gr Io”; 20 VI I685 r.: „Za traktament dla muzykantów pomagających in Festo Corporis Christi zt I”.

93 Wa Aug. 7, s. 55: 27 VII I633 r.: „Od oprawienia partesów fl. 3”; Wa Aug. 4I, k. 8v: 6 VI I68I r.: „Za sześć liber papieru do przepisowania śpiewania po gr 24 libra - zł 4 gr 24 ".

94 Wa Aug. 4I, k. 56v: 25 XI I683 r.: „Za piwo i wódkę dla muzykantów m[en]sis [!] i na Ś. Cecylię”.

95 Zob. np. ibid., k. 48v: 22 VI I683 r.: „Za strony do skrzypiec muzykowi zł 9”; k. $58 \mathrm{v}$ : Io I I684 r.: „Za motek stron do skrzypic na Święta przeszłe zł 3,IO”; k. 66v: 30 V I684 r.: „Na strony dla skrzypic zł I”; k. 80v: I4 III I685 r.: „Za strony do skrzypic na Passyjej i na traktament muzyków zł 5,IO”; k. 217: 3I VIII I69I r.: „Trębaczom, którzy na św. O. Augustyn[a] trąbili zł. 6”; k. 228: I6 VI I692 r.: „Trębaczom za całą oktawę kanonizacyjej [chodziło o uroczystości związane z kanonizacją hiszpańskiego augustianina Juana de Sahagún - B.P.-J.] i doboszom dwiema podczas procesyjej [też w trakcie uroczystości kanonizacyjnej - B.P.-J.] zł 25 gr I2". O zwyczaju grania z wieży kościoła św. Marcina i związanych z tym konfliktach pisze barwnie, wydaje się, że na podstawie źródeł, tu dotyczących roku 1699, Franciszek Maksymilian Sobieszczański (Dzielnica Staromiejska w Warszawie. Szkice historyczno-obyczajowe Franciszka Maksymiljana Sobieszczańskiego, zebrał Alexander Kraushar, Warszawa [1920] (= Biblioteka Dzieł Wybornych), s. II8). 
naście lat panowania Jana III Sobieskiego, informują również przy jakich okazjach klasztor był nawiedzany przez rodzinę królewską i towarzyszącą jej kapelę. Obecność kapeli króla Jana III w kościele św. Marcina w tym okresie jest potwierdzona wprost, tzn. z jednoznacznym stwierdzeniem, że chodziło o kapelę królewską, z okazji dnia św. Augustyna w 1. 1682, 1687, I689 i 1693 $3^{96}$, św. Wilhelma w I685 r.97, Wniebowzięcia N.M.P. w l. 1686 i $1693^{98}$ (według diariusza Giovanniego Battisty Fagiuolego, sekretarza nuncjusza Andrei Santacroce99, także w roku 1690 ${ }^{100}$ ) oraz św. Marcina

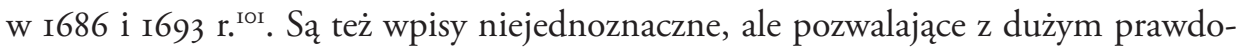
podobieństwem przyjąć, że zapisujący wydatki miał na myśli kapelę królewską. Tak jest na przykład w rachunkach za rok I68I, kiedy kapela występowała kilkakrotnie z okazji uroczystości, szczególnie czczonych przez augustianów, św. Augustyna, jego matki św. Moniki, św. Mikołaja z Tolentino i św. Tomasza z Villanova, a także Wniebowstąpienia Jezusa Chrystusa oraz Nawiedzenia i Wniebowzięcia N.M.P. ${ }^{102}$. Choć w odpowiednich wpisach występują określenia „muzyka”, „muzycy”, „PP. muzycy” czy „capella”, można mieć przekonanie, że chodziło o kapelę królewską (lub co najmniej jej część) z uwagi na wpis z Io sierpnia tego roku: „Na puł garnca wina dla Pana Rycerskiego ${ }^{103} \mathrm{z}$ kapelle J.K.M., który multoties laborat in omnibus festivitatibus [...] zł 3 gr 25 "104. Jest bardzo prawdopodobne, że zapisy dotyczące udziału muzyków w uroczystościach związanych z niektórymi spośród tych świąt obchodzonymi w innych latach też odnoszą się do kapeli królewskiej.

Jak pokazują wykorzystywane tu rachunki, w przypadkach gościnnych występów kapeli królewskiej podczas ważnych świąt koszty klasztoru ograniczały się zazwyczaj do poczęstunku dla członków kapeli w formie jedzenia i, przede wszystkim, trunków, najczęściej wódki i piwa, rzadziej wina. Zdarzało się jednak, że kapela królewska była niejako wynajmowana. Tak można interpretować zapis z I3 XI I686 r.: „P. Rokickiemu za exequie J.M.P. chorążego, które capella J.K.M. śpiewała zł 60”' ${ }^{\circ}$. Wydaje się, że „P. Rokicki” to w istocie kapelmistrz królewski Jacek Różycki, którego nazwisko

96 Wa Aug, 4I, k. 30v, I27, I65v, $243 \mathrm{v}$.

97 Ibid., k. 8I: 27 III I685 r.: „Za pułgarca wina dla kapelli królewskiej onegdaj zł 3”.

98 Ibid., k. IIov, 243.

99 Zob.: Gabriella Milan, „Fagiuoli Giovanni Battista”, w: Dizionario Biografico degli Italiani, t. 44, Roma I994, s. I75-I79, tu s. I76.

Ioo Zob.: „Diariusz podróży do Polski wydany z pamiętników Jana Chrzciciela Faggiuoli”, wyd. Władysław Kulczycki, Czas. Dodatek miesięczny t. II, rok 3 (I858), s. 262 (tu opis mszy I5 VIII I69o r. z udziałem króla Jana III Sobieskiego, nuncjusza Andrei Santacroce, z towarzyszeniem kapeli królewskiej).

IOI Wa Aug. 4I, k. II4: II XI I686 r.: „W dzień św. Marcina, gdy goście byli, rajcy, juristowie, capella J.K.M., za mięso, cielęcinę zł 25”; k. 247-247v: II i 25 XI I693 roku.

IO2 Ibid., k. 7v, 8v, 9v, I3v, I4v, I5, 30v.

I03 Jest wysoce prawdopodobne, że chodzi o Wawrzyńca (w łacińskojęzycznym źródle „Laurentius”) Rycerskiego, muzyka wymienionego 2I VI I675 r. w aktach chrztów za 1. I669-78 kościoła św. Jana Chrzciciela w Warszawie (Wa Par. św. Jana Io9, s. 4I4).

IO4 Wa Aug. 4I, k. I2v.

IOS Ibid., k. II4V. 
występuje w źródłach w wielu zniekształconych formach ${ }^{106}$. Zakonnicy zapłacili mu 60 zł za udział kapeli w mszy za duszę „J.M.P. chorążego”, można dodać na podstawie związanego z tą uroczystością innego wpisu, że chodziło o chorążego nadwornego koronnego $^{107}$, z wszelkim prawdopodobieństwem Wojciecha Prażmowskiego, zmarłego w I685 r. ${ }^{\text {I08 }}$, brata dobrodzieja klasztoru ks. Franciszka Prażmowskiego, wówczas sekretarza wielkiego koronnego (w przyszłości biskupa łuckiego), który zapewne bezpośrednio po śmierci Wojciecha zaordynował i zapłacił 70 zł (co odnotowano w rachunkach z I VII i685 r.), aby przez cały rok paliła się w kościele św. Marcina lampka przed obrazem Najświętszej Marii Panny ${ }^{109}$.

Kościół św. Marcina gościł także inne kapele, co poświadcza na przykład wpis w rachunkach z I2 V I693 r. „Dla kapelle Xią[żęcia] Jeg[omości] kardynała [Augustyna Michała Stefana Radziejowskiego, prymasa Polski - B.P.-J.] na wódkę gr II" "ıo. Można domniemywać, że kardynalscy muzycy uświetniali uroczystość św. Moniki (4 maja). O zespole tym nie wiadomo wprawdzie wiele, ale warto odnotować, że w I690 r. został do niego sprowadzony z Florencji śpiewak-kastrat Giuseppe Luparini. Nie jest jednak wykluczone, że w tym czasie należał on już do kapeli królewskiej ${ }^{\text {III }}$.

\section{ASPRILIO PACELLI}

Ponad dwudziestoletni okres działalności Asprilia Pacellego jako kapelmistrza na dworze królewskim Zygmunta III (I602-23) jest bardzo słabo udokumentowany źródłowo. Nie istnieją rachunki ani inne dokumenty kapeli królewskiej z tego czasu, a biografii muzyka z polskiego okresu jego działalności dotyczy tylko kilka znanych i zachowanych wzmianek w źródłach rękopiśmiennych ${ }^{\mathrm{II} 2}$. Informują one o orientacyjnym czasie przybycia do Krakowa (przed Bożym Narodzeniem I602 r.), dwukrotnie o udziale królewskiego kapelmistrza przy chrztach dzieci w kolegiacie św. Jana Chrzciciela w Warszawie, kiedy był ojcem chrzestnym (w I6II r. nie podano ani jego imienia, ani nazwiska, a jedynie

Io6 Zob. np.: Aleksandra Patalas, „Różycki Jacek”, w: Encyklopedia Muzyczna PWM, red. Elżbieta Dziębowska, t. 8, pe-r, Kraków 2004, s. 496 (co prawda forma „Rokicki” nie została tu odnotowana).

I07 Wa Aug. 4I, k. II4: 9 XI I686 r.: „Za ryby na extraordynaryjną porcją podczas exequii J.M. chorążego koronnego nadwornego zł 25 ”.

I08 Wg Adama Przybosia („Prażmowski Wojciech Remigian”, w: Polski Stownik Biograficzny, t. 28, Wrocław i in. I984-85, s. 336) przed Io IX I685 roku.

Io9 Wa Aug. 4I, k. 86: „Dało się do zakrystiej na światło przed obraz Naś[więtszej] Panny, które ordynował na cały rok, aby gorzało, J.M.X. Prażmowski, sekr[etarz] w[ielki] kor[onny], dobr[odziej] - zł 7o”.

IIo Ibid., k. 238.

III Zob.: Anna Szweykowska, „Luparini Giuseppe”, w: Encyklopedia Muzyczna PWM, red. Elżbieta Dziębowska, t. 5, klt, Kraków I997, s. 438.

II2 Są one wymienione w: Barbara Przybyszewska-Jarmińska, „Wstęp”, w: Asprilio Pacelli, Sacrae cantiones, wyd. B. Przybyszewska-Jarmińska, Warszawa 2012 (= Monumenta Musicae in Polonia, seria B: Collectanea Musicae Artis), s. 8-9. 
wskazano, że był to „Magister capellae S.R.M.”, a w roku I6ı4 został określony jako „Dominus Aspril[ius] magister capellae S.R.M.”푸), o pożyczce w wysokości IO25 florenów, jakiej udzielił nuncjuszowi papieskiemu Francesco Simonetcie (zm. w Polsce w I6I2 r.), o zwrot której zabiegał król Zygmunt III w Rzymie w I6I5 r., o legacie w wysokości 700 florenów, jaki Pacelli przekazał w testamencie, zapewne z I623 r., warszawskiemu Bractwu Miłosierdzia ${ }^{\mathrm{II}}$, oraz o legacie w wysokości 300 skudów, jaki pozostawił dla zespołu Cappella Giulia, którym kierował przed wyjazdem do Rzeczpospolitej (za te pieniądze miał być zakupiony złoty kielich z patena). Dwa znane źródła rękopiśmienne związane z tą ostatnią sprawą zostały wytworzone w Rzymie, już po śmierci muzyka (zm. 4 V I623 r., jak głosiła inskrypcja na epitafium ufundowanym przez Zygmunta III w kolegiacie św. Jana Chrzciciela, zniszczonym podczas powstania warszawskiego). W dokumentach tych Pacelli jest tytułowany w sposób przynależny osobom duchownym („Reverendus Dominus"), stąd w jednej z moich prac uznałam go za księdza ${ }^{\mathrm{II}}$, co w świetle pozostałych znanych obecnie źródeł uznaję za błąd.

Listę wymienionych wzmianek rękopiśmiennych o Pacellim można poszerzyć o dwie kolejne, z których jedna znajduje się w źródle augustiańskim, wielokrotnie już przywoływanym, przechowywanym w Bibliotece Narodowej w Warszawie Liber provinciae $^{\mathrm{II}}$. Znajduje się w nim odpis datowanego w Rzymie na 27 IV I623 r., pisanego po włosku listu generała augustianów Fulgentiusa a Monte Georgio do prowincjała Prowincji Polskiej" (był nim wspomniany już Andreas Simonides, który kilka poprzednich lat spędził na studiach we Włoszech i powrócił do Polski jako doktor świętej teologii $\left.{ }^{118}\right)$. W piśmie tym czytamy m.in.:

Pan Asprilio Pacelli, kapelmistrz Jego Królewskiej Mości, nie przybył na te święta [chodzi o Wielkanoc, która w I623 r. przypadała I6 kwietnia - B.P.-J.] ani nie dał żadnych wskazówek w sprawach, o których nam piszecie ${ }^{\Perp 1}$.

Niestety, nie znamy treści listu prowincjała, na który odpowiadał generał zakonu. Wydaje się jednak niewątpliwe, że znajdowała się w nim zapowiedź przyjazdu Pacellego do Rzymu, planowanego na Święta Wielkanocne 1623 roku. Kiedy list o. Fulgentiusa a Monte Georgio dotarł do Polski, królewski kapelmistrz już nie żył. Miejsce jego śmierci nie jest potwierdzone, ale z pewnością nie podjął on podróży do Włoch

II3 Wa Par. św. Jana I02, s. I87, 244.

II4 Wobec zaginięcia testamentu źródłem informacji jest dokonany na przełomie XIX i XX w. przez ks. Knapińskiego odpis z nieistniejących obecnie akt Archiwum Konsystorza Warszawskiego, zob. Kj 6948 II, k. 394 .

IIs Zob.: Barbara Przybyszewska-Jarmińska, Muzyczne dwory polskich Wazów, Warszawa 2007, s. 197.

II6 Wn akc. 6385 .

II7 Ibid., k. 62v-63.

II8 G. Uth, Szkic biograficzno-historyczny, s. 254.

II Wn akc.6385, k. 63: „Il Sig. Asprilio Pacelli, m[aest] ro di capella di S.M ${ }^{\text {tà }}$, non è capitato in queste feste, né ha dato ordine alcuno del neg[otiation]e che ci scrivete". 
i zmarł w Warszawie, a w każdym razie w Rzeczpospolitej. W zapisie sporządzonym na posiedzeniu kapituły św. Piotra w Watykanie in VI I623 r. znajduje się bowiem informacja na ten temat:

Przewielebny o. Paolo Bizzoni zawiadomił kapitułę, że w Polsce [podkreślenie B.P.-J.] umarł wielebny pan Asprilio Pacelli, niegdyś kapelmistrz naszej bazyliki, dla której zakrystii - z powodu czci i pamięci - przeznaczył 300 skudów monety rzymskiej, za które chciał, aby odlano złoty kielich wraz z pateną ${ }^{\text {I20 }}$.

Nie wiadomo, czy zmiana decyzji Pacellego i rezygnacja z wyjazdu do Rzymu była spowodowana chorobą, zagrożeniami związanymi z podróżą przez tereny objęte wojną i zarazą, długą, mroźną i śnieżną zimą, czy spodziewanym wyjazdem króla Zygmunta III, królowej Konstancji oraz królewicza Władysława, wraz z dworem (w tym kapela), do Golubia (do Anny Wazówny) i Gdańska oraz innych miast Prus Królewskich, a także Wielkopolski ${ }^{21}$, do którego doszło jednak z opóźnieniem, już po śmierci Pacellego (statki z orszakiem wypłynęły z Warszawy 9 maja $^{122}$ ). Choć nie wiadomo też, jaki był cel planowanego wyjazdu kapelmistrza do Italii, wydaje się bardzo prawdopodobne, że miał on związek ze sprawami podniesionymi w niewykorzystywanym dotąd w publikacjach liście, datowanym w Rzymie 24 VI I62I r., którego autorem był nieznany bliżej Giovanni Domenico Paolucci, a adresatem nieustalona wysoko postawiona osoba duchowna ${ }^{\mathrm{I2} 3}$. Z listu wynika, że rzymski urzędnik

I20 Rbav, Arch. Cap. di S. Pietro, Armadi I5, Decreti I2, I622-1638, k. I4: „Retulit in hoc capitulo Reverendissimus P. Paulus Bizonus obiisse in Polonia Reverendum Dominum Asprilium Pacellum, olim magistrum capellae huius nostrae basilicae, ob cuius venerationem et memoriam legavit sacristiae scuta trecenta monetae Romanae, de quibus voluit conflari calicem aureum cum patena”. Zob. też: B. Przybyszewska-Jarmińska, „Wstęp”, s. 8; Giancarlo Rostirolla, „Musicisti Umbri nella Cappella Giulia di San Pietro in Vaticano dalle origini agli inizi del Seicento. Con una nota sul magistero padovano di fra Rufino Cecchi Bartolucci di Assisi”, w: Arte e Musica in Umbria tra Cinquecento e Seicento. Atti del XII Convegno di Studi Umbri. Gubbio-Gualdo Tadino. 30 novembre-2 dicembre 1979, red. Biancamaria Brumana, Francesco F. Mancini, Gubbio 1981, s. I4I.

I2I Zob.: Stanisław Kobierzycki, Historia Wtadystawa, królewicza polskiego i szwedzkiego, wyd. Janusz Byliński i Włodzimierz Kaczorowski, przekł. Marek Krajewski, Wrocław 2005, s. 373-380.

I22 Zob.: Acta Nuntiaturae Polonae, t. 22, Joannes Baptista Lancelotti (I622-I627), cZ. I (22 XI 1622-3I XII I623), wyd. Thaddaeus Fitych, Cracoviae 200I, s. I2I-I22, I32-I34.

I23 KÓ 292 nr 39, k. 82: „Ill ${ }^{\mathrm{mo}}$ et Rev ${ }^{\mathrm{mo}}$ Sig. e Padron mio Colendissimo. Questa mattina ho consignato in propria mano al sig. Giovanne Carbone la lettera di V.S.Ill ${ }^{\mathrm{ma}}$, alla quale per hora non risponde altro, riportandosi a farlo congiuntamente alla riceuta dell'altra con la rimessa che promette di fare della seguente settimana. Dice l'istesso sig. Gio[vanne] che di Polonia non gl'è mai stato mandato ordine alcuno da presentare a V.S.Ill ${ }^{\mathrm{ma}}$, né in qualunque maniera da valersene, per l'esattione delli scudi 600 , né da S.M ${ }^{\text {tà }}$ o suoi ministri, né meno dal sig. Asprilio Pacelli, mastro di capella d'essa Ser ${ }^{\text {ma }} \mathrm{M}^{\text {tà }}$, creditore o ricevitore di tal summa. Ma ch'esso Pacelli gli scrisse alli mesi addietro qualmente il re haveva scritto et dato ordine per sue lettere a V.S.IIl ${ }^{\mathrm{ma}}$ che si pagassero qua al detto sig. Asprilio et per lui al esso sig. Gio[vanne] Carboni li predetti scudi 6oo; che però non essendogli caduto in pensiere di dargline detta parte, dopo haver atteso la comparsa loro un certo tempo et non giunta, scrisse al sig. Asprilio che sino a quell'hora non gl'erano stati pagati, che ancho però non haveva potuto essequire l'ordine suo in disponergli a voto di lui. Ch'è quanto intorno a ciò posso referire a V.S.Ill ${ }^{\mathrm{ma}}$, alla quale faccio humilissimamente riverenza, pregandole dal Signore la pienezza delle sue gratie. Di Roma li 24 giugno 162I. Di V.S.Ill ${ }^{\mathrm{ma}}$ et Rev $^{\mathrm{ma}}$ servitore humile e devotissimo Gio[vanni] Dom[eni]co Paolucci”. 
Giovanni Carbone zajmował się, na życzenie króla Zygmunta III i samego Asprilia Pacellego, ciągle niezałatwioną sprawą zwrotu wspominanego długu w wysokości I025 florenów (co po przeliczeniu wynosiło 600 rzymskich skudów), jaki zaciągnął u kapelmistrza nuncjusz Simonetta. Prowadzone na odległość starania o wyegzekwowanie spłaty długu były powiązane z załatwianiem planowanego przez Pacellego ustanowienia z tej sumy (lub może jej części) jakiegoś daru (chodziło zapewne o pieniądze, które ostatecznie stały się legatem dla Cappella Giulia, potwierdzonym przez cytowaną relację z posiedzenia kapituły św. Piotra). Wydaje się, że sprawa nie została załatwiona do początków I623 r., kiedy wierzyciel podjął zamysł udania się do Rzymu i osobistego dopilnowania odzyskania pieniędzy i przekazania daru, a suma przeznaczona dla Cappella Giulia została umieszczona w zaginionym dziś testamencie muzyka.

\section{MARCIN MIELCZEWSKI}

Nie w pełni wykorzystane przez muzykologów wiadomości do biografii Marcina Mielczewskiego przynosi rękopiśmienna książka rachunkowa Tabula censuum klasztoru św. Marcina, zawierająca głównie informacje o należnościach konwentu i donacjach na jego rzecz, obejmujące okres od XV do XVIII w., w najbardziej mnie tutaj interesujących częściach spisana w ostatniej ćwierci XVII stulecia ${ }^{124}$. Rękopis ten nabyło Muzeum Historii Warszawy (dziś Muzeum Warszawy), jak pisze autorka pierwszej pracy poświęconej temu rękopisowi, Jolanta Niklewska, „od syna i spadkobiercy poznańskiego kolekcjonera Jerzego Dobranieckiego, który wszedł w jego posiadanie w okupacyjnej Warszawie w 1940 r." ${ }^{225}$. Brak jakichkolwiek pieczęci świadczy, że wcześniej źródło nie należało do żadnej państwowej biblioteki i zapewne pozostawało w obiegu antykwarycznym. Zdaniem autorki ostatnim przed nią badaczem, który z tego rękopisu korzystał i dał temu wyraz w publikacji, był w XIX w. Julian Bartoszewicz $^{126}$. Jolanta Niklewska poddała analizie zawartość rękopisu ${ }^{127}$ i przekazała nieznane informacje, dotyczące m.in. zadłużenia Marcina Mielczewskiego i jego drugiej żony (jak dowiadujemy się z tego źródła, $2^{\circ}$ voto Kudelskiej), w związku z którym to zadłużeniem stanowiąca ich własność kamienica przeszła w I660 r., a więc niemal dziesięć lat po śmierci muzyka (zm. we wrześniu I65I r.) w posiadanie klasztoru św. Marcina ${ }^{\mathrm{I2}}$. Kiedy pisałam moją książkę poświęconą życiu i twórczości Marcina Mielczewskiego ${ }^{\mathrm{r} 29}$, ani omawiane źródło, ani prace Jolanty Niklewskiej nie były mi

I24 Wmhw A/I/326I. Na to źródło zwrócił moją uwagę mgr Piotr Jamski, za co mu serdecznie dziękuję.

I25 Jolanta Niklewska, „Nowy nabytek Muzeum Historycznego M. St. Warszawy”, Rocznik Warszawski 28 (1998), s. 323-331, tu s. 324 .

I26 Ibid., s. 324 .

I27 Jolanta Niklewska, „Tabula censuum warszawskiego kościoła Św. Marcina jako źródło poznania siedemnastowiecznych dochodów klasztoru", Almanach Muzealny 2 (1999), s. 85-Ioo.

I28 Ibid., s. 93.

I29 Barbara Przybyszewska-Jarmińska, Muzyka pod patronatem polskich Wazów. Marcin Mielczewski, Warszawa $20 \mathrm{II}$. 
niestety znane. Wykorzystałam je w pewnym zakresie w anglojęzycznej wersji mojej monografii ${ }^{130}$. Obecnie odnalezione w Archiwum Archidiecezjalnym w Poznaniu źródła dotyczące kamienicy Mielczewskiego każą mi powrócić do Tabula censuum oraz zweryfikować przedstawiane w moich publikacjach ${ }^{\mathrm{I3}}$ informacje o stanie posiadania muzyka u schyłku lat czterdziestych i w początkach następnej dekady oraz o lokalizacji wymienionej w jego ostatniej woli kamienicy zwanej Ludwikowska.

Z testamentu Mielczewskiego, sporządzonego 8 IX I65I r., a otwartego po jego śmierci przez wdowę Jadwigę Kołaczkównę w dniu 30 tegoż miesiąca i roku, znanego dziś jedynie z omówienia i drobnych ekscerptów opublikowanych przed II wojną światową przez Hieronima Feichta ${ }^{132}$, wynika m.in., że wraz z Jadwigą Kołaczkówną, jego ówczesną małżonką, Mielczewski nabył kamienicę zwaną Ludwikowską, której połowę zapisał żonie i ich wspólnemu synowi Franciszkowi Sylwestrowi, nakładając na nich obowiązek spłacenia ciążących długów. Wykorzystując informację o znanych w Starej Warszawie od XVI w. kamienicach Ludwikowskich ${ }^{\mathrm{I3}}$, nazywanych także, po ich połączeniu, kamienicą biskupów poznańskich, tuż przy południowo-wschodnim rogu Rynku Starego Miasta (obecnie ul. Jezuicka 6), tak jak Andrzej Sołtan ${ }^{134}$ uważałam, że części tej właśnie kamienicy dotyczyła wzmianka w ostatniej woli muzyka ${ }^{\mathrm{I} 35}$. Równocześnie wiedziałam o tym, że Mielczewski jeszcze w I650 r. był właścicielem murowanego domu za bramą nowomiejską ${ }^{136}$, który sytuowałam przy ul. Mostowej, przyjmując za dobrą monetę informację podaną przez Aleksandra Polińskiego, według której kamienicę na Mostowej wniosła muzykowi w posagu jego druga żona, Jadwiga Kołaczkówna ${ }^{137}$. Wobec faktu, że w testamencie wymieniona jest tylko jedna kamienica, zakupiona wspólnie przez oboje małżonków, postawiłam hipotezę, iż w ostatnim roku życia Mielczewski musiał dom za murami Warszawy sprzedać, a kupić w pobliżu Rynku znaną varsavianistom kamienicę Ludwikowską ${ }^{138}$.

W świetle Tabula censuum oraz nowo odnalezionych źródeł zachowanych w aktach biskupów poznańskich hipoteza ta okazuje się błędna. W szczególności rozu-

I30 Barbara Przybyszewska-Jarmińska, Marcin Mielczewski and Music under the Patronage of the Polish Vasas, przekł. John Comber, Frankfurt am Main 2014 (= Eastern European Studies in Musicology 3), s. 39.

I3I Poza wymienionymi także w: Barbara Przybyszewska-Jarmińska, „Marcin Mielczewski - życie i dorobek”, w: Marcin Mielczewski. Studia, red. Zygmunt M. Szweykowski, Kraków 1999, s. 7-26.

I32 Hieronim Feicht, „Przyczynki do dziejów kapeli królewskiej w Warszawie za rządów kapelmistrzowskich Marka Scacchiego", Kwartalnik Muzyczny I (I929) nr 2, s. I38-I39; przedruk w: H. Feicht, Studia, s. $280-282$.

I33 F. M. Sobieszczański, Dzielnica staromiejska, s. 99.

I34 „Mielczewski [...]. Był właścicielem części kamienicy Ludwikowskiej przy Rynku SW”, Andrzej Sołtan, „Muzycy warszawscy w latach I583-1655”, Rocznik Warszawski I8 (1985), s. 52.

I35 B. Przybyszewska-Jarmińska, Muzyka pod patronatem, s. 79; tejże, Marcin Mielczewski and Music, s. 84.

I36 Potwierdzał to zapis z I5 VI I650 r. w księdze chrztów za 1. I649-59 Parafii św. Jana Chrzciciela w Warszawie, zob.: Wa Par. św. Jana I07, s. 42 i 6I; zob. też: B. Przybyszewska-Jarmińska, Muzyka pod patronatem, s. 77.

I37 Aleksander Poliński, „Mielczewski Marcin”, w: Wielka Encyklopedia Powszechna Ilustrowana, seria I, t. 47-48, Warszawa I9I2, s. IO-II, tu s. Io.

I38 B. Przybyszewska-Jarmińska, Muzyka pod patronatem, s. 79; tejże, Marcin Mielczewski and Music, s. 84, 86-87. 
mowanie moje falsyfikują dokumenty $\mathrm{z}$ tych ostatnich akt, powstałe $\mathrm{w}$ Warszawie 22 XII 1648 r., wraz z ich zatwierdzeniem z Io I I650 r. dokonanym, także w Warszawie, przez ówczesnego biskupa poznańskiego Andrzeja Szołdrskiego ${ }^{139}$. Będąca w posiadaniu Mielczewskiego, Kołaczkówny ${ }^{140}$ i Jana Kołaczka (wikarego, mansjonarza i altarzysty w kościele N.M.P. w Warszawie na Nowym Mieście, zapewne członka rodziny żony muzyka) kamienica za bramą nowomiejską, przy ul. Mostowej, została w nich określona jako od dawna znana pod nazwą Ludwikowska ${ }^{\mathrm{I} 4 \mathrm{I}}$. Tym samym można stwierdzić z pewnością, że Mielczewski w ostatnich latach życia był współwłaścicielem (wraz Janem Kołaczkiem i małżonką, która poniosła jaką̧s część kosztów zakupu) tylko jednej kamienicy, tej właśnie umiejscowionej przy bramie zwanej Nową (w tym czasie był to kompleks trzech bram nowomiejskich, kończących się tzw. furtą na wysokości kościoła św. Ducha ${ }^{\mathrm{I} 2}$ ), na północnym przedmieściu Warszawy, które pozostawało pod jurysdykcją Starego Miasta ${ }^{\mathrm{I}}{ }^{3}$. Określenie kamienica Ludwikowska nie występuje w odniesieniu do tej nieruchomości w żadnych innych, poza testamentem i wspomnianymi, dotąd przez badaczy niewykorzystywanymi, dokumentami $\mathrm{z}$ akt biskupich, znanych mi źródłach ani w literaturze przedmiotu. Pochodzi ono zapewne od nazwiska Piotra Ludwika, który jest wymieniony w opublikowanych w 1963 r. spisach poboru Starej Warszawy z i640 r. jako właściciel kamienicy przy ul. Mostowej ${ }^{144}$. Ta kamienica była identyfikowana piętnaście lat później, we wrześniu I655 r., z kamienicą Mielczewskiego/Milczewskiego alias Kudelskiego w wykazie określonym jako Descripcyja albo komput kamienic, sporządzonym dla Szwedów po zajęciu przez nich Warszawy, oraz w kontrybucji szwedzkiej Starej Warszawy z kwietnia

I39 Pa AE XXXIV (1646-1650), bez foliacji.

I40 Nazwisko muzyka, określonego jako „Serenissimi Principis Caroli Ferdinandi Poloniae et Sueciae Principis, episcopi Plocensis, capellae mag[iste] r”, zostało podane w formach: „Mielczewski”, „Milczewski” i „Micielski”, a jego żony: „Kołaczkowa”, „Kołaczkowicówna” i „Miciewska”.

I4I Pa AE XXXIV: „Erectio ex fundatione famatae Annae Borakowcząnka in ecclesia Sanctae Crucis extra Varsaviam”, zatwierdzenie z Io I I650 r. dwóch inserowanych dokumentów z 22 XII I648 r. („feria tertia in crastino festi Sancti Thomae Apostoli anno Domini Millesimo Sexcentesimo Qudragesimo Octavo"). W drugim z nich jest mowa o rocznych odsetkach w wysokości i4O zł, płatnych w dwóch ratach (na Wielkanoc i na św. Michała) od pożyczki w wysokości 2000 zł, zaciągniętej przez Mielczewskiego, wraz z Jadwigą Kołaczkówną oraz Janem Kołaczkiem, zabezpieczonej „in et super domo sua lapidea Ludwikowska antiquitus nuncupata hic in Varsaviensi suburbio [in] platea Pontali”. Uzyskane od wyżej wymienionych środki miały stanowić podstawę ustanowionej przez Annę Borakowską/Borakowczankę fundacji altarii w kościele św. Krzyża.

I42 Zob.: Aleksander Wejnert, Starożytności Warszawy. Dzieto zbiorowo-zeszytowe, t. I, Warszawa I848, s. IO6-IIO i plan po s. I24.

I43 Stąd wdowa po Mielczewskim, Jadwiga Kołaczkówna, została 4 IV 1653 r. obywatelką Starej Warszawy, zob.: B. Przybyszewska-Jarmińska, Muzyka pod patronatem, s. 80.

${ }_{144}$ Źródta do dziejów Warszawy. Rejestry podatkowe i taryfy nieruchomości I5IO-I770, wyd. Anna Berdecka, Janina Rutkowska, Anna Sucheni-Grabowska, Hanna Szwankowska, Warszawa 1963, s. 72 (identyfikacja domu Piotra Ludwika pochodzi od redaktorek wydawnictwa, Anny Sucheni-Grabowskiej i Hanny Szwankowskiej; wspierają ją wpisy w księdze chrztów parafii św. Jana Chrzciciela w Warszawie z października I64I r., w których Piotr Ludwik, szewc z ul. Mostowej, występuje jako ojciec chrzestny, zob. Wa Par. św. Jana Io6, s. 65 i 66. 


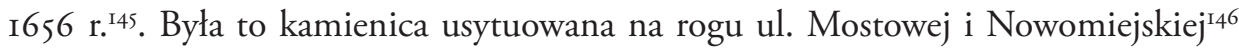
(naprzeciwko budynku szpitala św. Ducha), którą w taryfie posesji Warszawy z I77o r. opatrzono w wykazie domów w ramach ulicy Mostowej numerem I (numery rosły w stronę Wisły) ${ }^{\mathrm{I} 7}$, w drukowanej taryfie miasta Warszawy z roku I784 nadano numer hipoteczny $236^{148}$, a jeszcze później, obowiązujący od ostatnich dziesięcioleci wieku $\mathrm{XIX}^{\mathrm{I} 49}$ do dzisiaj, numer adresowy Mostowa 29. Tabula censuum oraz dokumenty z akt biskupów poznańskich wyjaśniają, o jakich długach wspominał w testamencie Mielczewski. Stanowiły one obciążenie kamienicy. Wobec niemożności dokonania spłaty długu przez wdowę, która między rokiem I653 a I655 wyszła ponownie za mąż, za Kudelskiego (nieznanego imienia ${ }^{\mathrm{I5}}$ ), zrujnowana w okresie okupacji szwedzkiej kamienica została w I660 r. odbudowana przez oo. augustianów, którzy byli jednymi z wierzycieli Marcina Mielczewskiego, a następnie małżeństwa Kudelskich. Wówczas też przeszła ona w połowie w posiadanie klasztoru św. Marcina, podczas gdy druga połowa pozostała przy Kudelskiej ${ }^{151}$. Zarówno w rejestrach podatkowych z lat I655, I656, I659 i I669 $9^{152}$, jak i w Tabula censuum ${ }^{\mathrm{I53}}$ oraz w rachunkach konwentu św. Marcina związanych z remontem nieruchomości oraz goszczeniem w klasztorze jej podnajemców w latach osiemdziesiątych i dziewięćdziesiątych XVII w. ${ }^{154}$, a więc w źródłach powstałych od kilku do około czterdziestu lat po śmierci Mielczewskiego, kamienica określana jest jego nazwiskiem w formie Milczewski (rzadziej kamienica Milczewskich, najczęściej kamienica Milczewska'55, wyjątkowo z uwzględnieniem własności Kudelskiego lub Kudelskich - w I655 i I656 r. „Kam. Milczewsky alias Kudelski”, w I659 r. „Kamienica Milczewskiego, teraz Kudulskiego: izdeb 4, sklepów 3, puste" $\left.{ }^{156}\right)$. Dopiero w wymiarze podatku łokciowego Miasta Starej Warszawy z I743 r. kamienica („kamieniczka”) o tej lokalizacji, znowu w złym stanie i niezamieszkała,

I45 Aleksander Wejnert, Starożytności Warszawy. Dzieto zbiorowe, t. 4, Warszawa I856, s. I58; Źródta do dziejów, s. II3.

I46 Tak też: J. Niklewska, „Tabula censuum”, s. 93.

I47 Źródta do dziejów, s. 464.

I48 Taryffa miasta Warszawy [...] w roku I784, [Warszawa I786], k. A (w tym czasie właścicielem gruntownie już przebudowanej kamienicy był niejaki S. Szarkowski).

I49 Tabel'domam" g. Varšavy i predměst'â Pragi, [Varšava] I887, s. 9.

I50 Niewykluczone, że był to Andrzej Kudelski, wymieniony w księdze chrztów Parafii św. Jana Chrzciciela w Warszawie jako ojciec chrzestny przy chrzcie Jana, syna Marianny Przybyszówny, który odbył się Io IV I65I r., zob. Wa Par. św. Jana I07, s. 8I.

I5I Wmhw A/I/326I, k. I2-I2v; J. Niklewska, „Tabula censuum”, s. 93.

I52 A. Wejnert, Starożytności Warszawy, t. 4, s. 158; Źródta do dziejów, s. II3, I82 (w taryfie z I659 r. błędnie umieszczono wpis dotyczący kamienicy po tej samej stronie ul. Nowomiejskiej co kościół św. Ducha, zamiast po przeciwnej), 232.

I53 Wmhw A/I/326I, k. I2, 32v, II9, 204.

I54 Wa Aug. 4I, k. 33V, 48v, 55, 64, 78, 86v, II4V, I56, I57-I58v, I60, I65, I65V, I67, I7I, I7IV, I83V, I86, I87V, I88, I9I-I92, I93, I93V, I95-I97V, 220, $220 \mathrm{~V}$.

I55 Tak bez wyjątku w Wmhw A/I/326I oraz Wa Aug. 4I.

I56 Źródta do dziejów, s. II3, I82. 
nie nosi żadnej nazwy ${ }^{157}$. Najwyraźniej o Mielczewskim jako jej dawnym właścicielu już zapomniano. W spisie mieszkańców i nieruchomości z I754 r., czyli tzw. Lustracji Dawidsona, wymieniona została z tą samą lokalizacją „Kam[ienica] ww. oo. Augustyjanów pusta" ${ }^{\text {"58 }}$, wobec czego nie pobierano od niej podatku ${ }^{159}$.

Co do okoliczności zakupu kamienicy i związanych z tym długów wiadomo z Tabula censuum, że Mielczewski w I648 r. pożyczył 8000 zł. W tej sumie znalazł się depozyt 2000 zł, który przekazali jako dar dla klasztoru św. Marcina małżonkowie Mikołaj Jeleniewicz i Anna Borakowska, a zabezpieczeniem była nowo zakupiona kamienica Mielczewskich ${ }^{160}$, oraz Iooo zł od muzyka królewskiego Wardyńskiego ${ }^{16 \mathrm{I}}$ (można dodać, że był to królewski teorbista Bartłomiej Wardyński, który zmarł, podobnie jak Mielczewski, w drugiej połowie I65I r. ${ }^{162}$ ). Według Polińnkkiego, który powoływał się na nieistniejące dziś księgi Starej Warszawy, Mielczewski pożyczył też w I648 r., zapewne na ten sam cel, 6000 zł od lekarza królewskiego [Andrzeja] Lewińskiego, które w następnym roku w całości spłacit ${ }^{163}$. W świetle tych informacji można przypuszczać, że w ostatnich latach życia kapelmistrz biskupa Karola Ferdynanda, obdarzony przez swego patrona dzierżawą folwarku Niemirów koło Wyszkowa (zatwierdzoną przez kapitułę generalną płocką 4 V I649 r.) ${ }^{164}$, musiał uważać swoją sytuację materialną za na tyle dobrą, że mógł sobie pozwolić, choć z koniecznością zaciągnięcia pożyczek, z których większość zresztą zdążył spłacić, na zakup, stosunkowo niedaleko od centrum Starej Warszawy, dość obszernego domu, w tym czasie jednego z nielicznych murowanych w okolicy, gdzie zdecydowaną większość stanowiły domy drewniane. Z pewnością nie przewidywał wówczas swojej bliskiej śmierci ani nadchodzących wydarzeń związanych z ,potopem” szwedzkim, które doprowadziły do zubożenia jego rodziny oraz ostatecznej utraty przez nią kamienicy „Milczewskiej”.

\section{BARTŁOMIEJ PĘKIEL}

Wzmianki o Bartłomieju Pękielu znajdujemy z różnych powodów na dwóch stronach w Tabula censuum. Po raz pierwszy w związku z wsią Ujazdów, której część stanowiła od XV w. własność warszawskiego klasztoru św. Marcina, i której odstąpienie

\footnotetext{
I57 Ibid., s. 329.

I58 Ibid., s. 436.

I59 O dalszych losach kamienicy zob.: Jarosław Zieliński, Atlas dawnej architektury ulic i placów Warszawy, t. II, Miechowska-Myśliwiecka, Warszawa 2005 (= Biblioteka Towarzystwa Opieki nad Zabytkami), s. $426,430-431$ oraz zdjęcia na s. 644.

I60 Chodzi o sumę stanowiącą podstawę wzmiankowanej fundacji w kościele św. Krzyża, zob. przyp. I4I.

I6I Wmhw A/I/326I, k. I2; J. Niklewska, „Tabula censunm”, s. 93.

I62 B. Przybyszewska-Jarmińska, Muzyczne dwory, s. 219. W 1648 r. Wardyński kupił od Marcina Mielczewskiego za sumę 2500 florenów grunt wraz z zabudowaniami w Ujazdowie, zob.: H. Feicht, Studia, s. 279; B. Przybyszewska-Jarmińska, Muzyka pod patronatem, s. 72-73.

I63 A. Poliński, „Mielczewski Marcin”, s. Iо.

I64 B. Przybyszewska-Jarmińska, Muzyka pod patronatem, s. 74.
} 
na zasadzie niekorzystnej dla augustianów umowy z I6I9 r. (z zamianą Ujazdowa na grunty we wsi Dąbrówka koło Piaseczna) wymusił na nich Zygmunt III. Augustianie złożyli protest, ale nie wystąpili do sądu przeciwko temu królowi ani jego następcom z dynastii Wazów, ani też mniejszym właścicielom w Ujazdowie, spośród których w omawianym źródle szczególną uwagę poświęca się Bartłomiejowi Pękielowi ${ }^{165}$. Z Tabula censuum poznajemy bowiem historię nabycia i sprzedaży Ujazdowa przez Pękiela, podając jako marginalium, że dostał on przywilej od króla Władysława IV w I635 r., objął majątek w I637 r., po czym sprzedał go kanclerzowi wielkiemu litewskiemu Krzysztofowi Pacowi w roku I659 ${ }^{166}$, a w zasadniczym tekście czytając:

Vladislaus IV rex [...] dał te dobra [tj. Ujazdów - B.P.-J.] Bartholomeo Pękiel, capellae magistrowi, swemu muzykowi ${ }^{167}$, który one possidebat i za króla J.Mci Kazimierza IV [Jana Kazimierza - B.P.-J.] [...]. Po Pekielu tych dóbr ujazdowskich połowa przyszła była w possessyją Mci Panu Theodorowi Denhoffowi, podkomorzemu koronnemu, etc. etc., a drugą połowę kupił był u Pekella J.M.P. Krzysztof Pac, kanclerz wielki litewski ${ }^{168}$.

Augustianie dopiero od lat siedemdziesiątych XVII w. starali się wyegzekwować od Denhoffa i Paca rekompensatę za tę ziemię ${ }^{169}$. Co do Pękiela, jeżeli daty podane w Tabula censuum są ścisłe, pierwsza z nich (rok I635) byłaby najwcześniejszą potwierdzającą działalność muzyka na dworze Władysława $\mathrm{IV}^{\mathrm{I70}}$. O tym, że Pękiel był właścicielem posiadłości w Ujazdowie przed 9 I I64I r., wiedział już niemal sto lat temu Hieronim Feicht $\mathrm{z}$ tak datowanego aktu, dotyczącego innego nadanego muzykowi przywileju ${ }^{171}$. Natomiast rok sprzedaży gruntu Krzysztofowi Pacowi jest potwierdzony dwoma zachowanymi do dzisiaj, znanymi także Feichtowi, dokumentami ${ }^{172}$.

I65 Sprawa własności Ujazdowa opisana jest w Wmhw A/I/326r, k. 34-36v. Zob. też: J. Niklewska, „Tabula censuum", s. 88-89.

I66 Wmhw A/I/326I, k. 36v: „An[no] I635 privilegium Pekellemu dał K.J.M. Vładysław Czwarty, I637 intromissus Pekel in bona Jazdów, 1659 Pekel cedit ius M.D. cancellario M[agni] D[ucatus] Litu[aniae] in castro Varsav[iensi], I659 oblata eiusdem cessionis ad Metricam” (w tym i innych cytatach z tego źródła zachowano występujące w nim warianty nazwiska muzyka).

I67 Kiedy Władysław IV nadawał dobra Pękielowi, nie był on jeszcze kapelmistrzem, został nim kilka lat po wyjeździe Marka Scacchiego do Włoch, między 1653 i 1654 rokiem.

I68 Wmhw A/I/326I, k. 36v.

I69 J. Niklewska, „Tabula censuum”, s. 88-89.

I70 Najwcześniejsza dotąd znana wzmianka to 27 III I637 r., kiedy muzyk, tytułowany jako królewski organista, jest wymieniony jako ojciec chrzestny w aktach metrykalnych kościoła św. Jana Chrzciciela w Warszawie, zob.: Anna Szweykowska, „Notatki dotyczące kapeli królewskiej w XVII wieku”, Muzyka I6 (I97I) nr 3, s. 92.

I7I Hieronim Feicht, „Kompozycje religijne Bartłomieja Pękiela”, Lwów I925, maszynopis, wyd. w: H. Feicht, Studia, s. 303-304.

I72 H. Feicht, Studia, s. 296 i 305. Cytaty z tych źródeł zob.: Zofia Dobrzańska-Fabiańska, „Wstęp”, w: Bartłomiej Pękiel, Opera omnia, t. I, Utwory wokalno-instrumentalne, wyd. Z. Dobrzańska-Fabiańska, Kraków 1994 (= Monumenta Musicae in Polonia, seria A: Opera omnia), s. 8-9. 
Wydaje się, że większe znaczenie ma jednak inny występujący w omawianym źródle zapis, umieszczony wśród wpłat dokonywanych przez różne osoby na rzecz klasztoru. Ostatnią wymienianą w publikacjach dotyczących Pękiela pewną datą odnoszącą się do niego jako osoby żyjącej jest 23 VIII i664 r., kiedy datowano zachowany w Archiwum Krakowskiej Kapituły Katedralnej na Wawelu (Acta Actorum Capitularia) dokument informujący, że muzyk, będący wówczas kapelmistrzem kapeli na Wawelu, udawał się do króla, jak domniemuje Zofia Dobrzańska-Fabiańska, być może do Warszawy ${ }^{173}$. Czy, kiedy i na jak długo wrócił do Krakowa, nie wiadomo. $\mathrm{Z}$ uwagi na fakt, że w tym samym archiwum na Wawelu zachowała się wzmianka z 3 X 1670 r., stanowiąca najwcześniejsze potwierdzenie działalności w zespole muzycznym krakowskiej kapeli katedralnej w charakterze kapelmistrza Daniela Fierszewicza ${ }^{174}$, w biogramach Pękiela podaje się, że zmarł on około 1670 r. ${ }^{175}$ (takie datowanie śmierci muzyka wynika z założenia, niepotwierdzonego źródłowo, że Fierszewicz był jego następcą i że został kapelmistrzem w 1670 r.). W świetle Tabula censuum Pękiel zmarł już w 1666 roku. W rękopisie tym znajduje się wpis darowizny na rzecz klasztoru dokonanej 9 I 1646 r.: „od J.M.P. Bartłomieja Pekiella (był magister capellae królewskiej) kolendy wziął konwent fl. Io, ale i przedtym i potym dobrze czynił i życzył konwentowi, i grawał"176. Zapisowi towarzyszą sporządzone tą samą ręką dopiski: „defunctus est an[no] 1666 fl. I5” oraz „It[em] Ich MM. PP. exequutores pagi fl. I0o"177, które mogą oznaczać, że Pękiel zmarł w Warszawie i tam (w kościele św. Marcina) odbył się jego pogrzeb, ale niewykluczone, iż odnoszą się jedynie do mszy za duszę muzyka oraz wypłaty klasztorowi przez egzekutorów jego testamentu legatu w wysokości Ioo fl., ujętego w ostatniej woli. W tym drugim przypadku wpis ten nie stanowiłby informacji o miejscu śmierci i pochówku Pękiela.

\section{ADEODATO BAROCHIUS I ALFONSO SELVATICI}

W Xenia Apollinea, dodatku nutowym do Cribrum musicum Marca Scacchiego (Wenecja I643) został m.in. zamieszczony kanon opatrzony wskazaniem autora sporządzonym po łacinie: „R[everendi] P[atris] Adeodati Barochii, Ord[inis] Eremit[arum] S[ancti] August[ini] et Reg[iae] Maiestatis capellani et musici”'178. Jest to jedyne znane

173 Z. Dobrzańska-Fabiańska, „Wstęp”, s. 9.

174 Ibid.

175 Zob. np.: Mirosław Perz, „Pękiel Bartłomiej”, w: Grove Music Online, 200I, https://doi.org/ı.Io93/ gmo/9781561592630.article.21208, dostęp 24 IV 2020; Zofia Dobrzańska-Fabiańska, „Pękiel Bartłomiej”, w: Encyklopedia muzyczna PWM, t. 8, pe-r, s. 83-87, tu s. 83; B. Przybyszewska-Jarmińska, Muzyczne dwory, s. 20I.

I76 Wmhw A/I/326I, k. 54v. Zob. też: J. Niklewska, „Nowy nabytek”, s. 329; tejże, „Tabula censuum”, s. 88.

177 Wmhw A/I/326I, k. 54v.

I78 Marco Scacchi, Cribrum musicum, Venezia: Alessandro Vincenti, I643, s. 206. Na tej podstawie Adeodatus Barochius znalazł się w słowniku Roberta Eitnera, zob.: „Barochius Adeodatus”, w: Biographisch-Bibliographisches Quellen-Lexikon der Musiker und Musikgelehrten, t. I, Leipzig I900; przedruk, t. I, Graz 1959, s. 345. 
oryginalne źródło z XVII w., w którym zostało podane nazwisko (w zlatynizowanej formie) tego augustianina, będącego kapelanem i muzykiem Władysława IV. Jego działalność w kapeli królewskiej jest potwierdzona jeszcze w pierwszych latach panowania Jana II Kazimierza. W zachowanych rachunkach z 1. 1650-52 jest wymieniony, w grupie śpiewaków - basów, jedynie pod imieniem, jako „X. Deodato” lub „X. Theodato”, który w I650 i I65I r. otrzymywał I200 florenów rocznej pensji179. Z tego samego źródła wiadomo, że I7 III I652 r. dostał „z łaski króla Jego Mości fl. 6oo”, jako odprawę, oraz $300 \mathrm{fl}$. za miesiące od stycznia do marca tego roku ${ }^{180}$. Barochius opuścił zatem kapelę w marcu 1652 roku. Kiedy został do niej przyjęty, nie wiadomo. Według dotychczasowego stanu badań na pewno był śpiewakiem królewskim związanym z klasztorem św. Marcina w Warszawie w lutym I640 roku. Wówczas powstał dokument określający warunki, na których cech warszawskich złotników, dysponujący kaplicą św. Anny w tym kościele, wyrażał zgodę, aby augustianin, muzyk królewski, wystawił w tej kaplicy ołtarz św. Anioła Stróża. Niestety, oryginalnego dokumentu, zapewne łacińskojęzycznego, znajdującego się niegdyś w aktach biskupów poznańskich, nie udało się znaleźć. Jest on przytaczany w polskim tłumaczeniu w dziewiętnastowiecznej pracy Józefa Łukaszewicza, który - jak się zdaje - przełożył na polski także nazwisko muzyka, podając je w wersji „Barocki” ${ }^{\prime 2}$. Najpewniej nie znając tej publikacji, tak samo przetłumaczył zlatynizowane nazwisko tego augustiańskiego śpiewaka już w XX w. Zdzisław Jachimecki, dokonując także przekładu jego imienia. Kiedy w swoim wydanym w I909 r. artykule wymienia on muzyków, których kanony zostały zamieszczone w Xenia Apollinea, pisze m.in. „Adeodatus Barochius był pewnie Polakiem i może nazywał się Bogdan Barocki”'182. Już w sposób definitywny o przynależności Bohdana (nie Bogdana) Barockiego do grona muzyków polskich pisze w kolejnych pracach, wydanych w 1 . 1914-48 ${ }^{183}$, w czym jest początkowo naśladowany przez Adolfa Chybińskiego i Hieronima Feichta. Chybiński pisał w publikacji z 1927 r.: „W wydanym w r. 1643 Cribrum mieści się wiele kanonów zaopatrzonych polskiemi nazwiskami (Adamecki, Barocki [...])"184. Feicht zaś, powołując się na pracę Jachimeckiego, napisał w swoim artykule z 1929 r.:

I79 Anna Szweykowska, „Kapela królewska Jana Kazimierza w latach I649-I652”, Muzyka I3 (I968) nr 4, s. $40-48$, tu s. 42 i 44 .

I80 Ibid., s. 44 (autorka w tekście własnym, niestanowiącym cytatu źródła, nazywa muzyka „Theodato Barocchio").

I8I J. Łukaszewicz, Krótki opis historyczny, s. 93-94.

I82 Zdzisław Jachimecki, „Kontrapunkciści polscy w kapeli Władysława IV”, Mtoda Muzyka 2 (I909) nr I9, s. $3-5$, tu s. 4 .

I83 M.in.: Zdzisław Jachimecki, Rozwój kultury muzycznej w Polsce, Kraków I9I4, s. 87; tegoż, Historia muzyki polskiej (w zarysie), Warszawa-Lublin-Łódź-Poznań-Kraków I920, s. 89; tegoż, „Muzyka polska od I572 - I795”, w: Polska, jej dzieje i kultura od czasów najdawniejszych do chwili obecnej, t. 2, I572-I795, red. Stanisław Lam, Warszawa [1929], s. 550; tegoż, Muzyka polska w rozwoju historycznym od czasów najdawniejszych do doby obecnej, t. I, Od Bogurdzicy do Chopina wtącznie, cz. I, Kraków I948, s. 200.

I84 Adolf Chybiński, „Z dziejów muzyki polskiej do I8oo roku”, Muzyka 4 (I927) nr 7-9 (nr specjalny pt. Muzyka polska pod red. Mateusza Glińskiego), s. 52. 
„Z całego poważnego szeregu polskich kontrapunkcistów brak nam jeszcze dotąd wiadomości o Adeodacie Barochiusie (nazywającym się przypuszczalnie według Z. Jachimeckiego Bohdanem Barockim)"'185. Obaj ci badacze zmienili z czasem zdanie, czego świadectwem są ich publikacje wydane po II wojnie światowej. W Stowniku muzyków polskich Chybiński pisze: „Barochius (Barocchio?) Adeodat, włoskiego pochodzenia mnich zak. Augustianów, kapelan i członek kapeli król. w Warszawie ok. r. I643"186; nie podając podstawy swojego przekonania o włoskim rodowodzie muzyka, proponuje reitalianizację jego nazwiska. Tym śladem poszedł Hieronim Feicht, informując, jako pierwszy muzykolog, że „Barochius (Barocchio włoskiego pochodzenia, czy też po prostu Barocki, jak pisze Łukaszewicz" należał do kapeli królewskiej już w I640 r. ${ }^{187}$. Takie też informacje o tym zakonniku-śpiewaku podano w Stowniku muzyków polskich pod redakcją Józefa Chomińskiego ${ }^{188}$. Do kwestii pochodzenia muzyka nie odniosła się Anna Szweykowska we wspominanym artykule opublikowanym w 1968 r., ale w haśle w Encyklopedii muzycznej PWM podała, że Adeodatus Barochius był włoskim śpiewakiem $^{189}$, a w książce wydanej wspólnie z Zygmuntem M. Szweykowskim w roku 1997 wymieniła Deodata Barocchia wśród muzyków włoskich ${ }^{190}$. Włoskie pochodzenie, jako niepodlegające dyskusji, podane jest również w słowniku muzyków wazowskich zamieszczonym w pracy piszącej te słowa ${ }^{191}$.

Jakkolwiek intuicja nie zawiodła tych muzykologów, którzy uznali Barochiusa za Włocha, trzeba stwierdzić, że nie wskazywali oni dotąd jakichkolwiek źródeł dokumentujących taki stan rzeczy. Jego włoskiego pochodzenia dowodzą natomiast niewykorzystywane dotąd przez badaczy w ogóle lub pominięte przez historyków muzyki źródła augustiańskie, inna rzecz, że w żadnym z nich nie jest on określany nazwiskiem. W aktach kapituł prowincji polskiej augustianów, w których wymieniani są zakonnicy z poszczególnych klasztorów, występuje w l. I634, I637, I640 i 1646 należący do familii warszawskiej „V[enerabilis] P[ater] S[acrae] T[heologiae] B[accalaureus] Adeodatus Perusinus", o którym wiadomo ponadto, że w I646 r. przewodniczył odbywającej się w Warszawie kapitule prowincji1 ${ }^{192}$. Zważywszy na rzadkie,

I85 H. Feicht, „Przyczynki”, s. I4I, przedruk w: H. Feicht, Studia, s. 285.

I86 Adolf Chybiński, Stownik muzyków dawnej Polski do roku I8oo, Kraków [I949], s. 5.

I87 H. Feicht, „Muzyka w okresie polskiego baroku”, s. I66; przedruk w: H. Feicht, Studia, s. Ior. Pomimo znajomości Stownika Chybińskiego, wiedząc o wersji nazwiska podanej przez Łukaszewicza, Wacław Kmicic-Mieleszyński zdecydował się, pisząc artykuł na temat Cribrum musicum, zaliczyć Barochiusa do Polaków, zob.: Wacław Kmicic-Mieleszyński, „Geneza Cribrum musicum”, Muzyka 2 (1957) nr 3, s. I2: „Ks. Adeodat Barochius (Ks. Bohdan Barocki) Polak I kanon”.

I88 Stownik muzyków polskich, t. I, s. 222.

I89 Anna Szweykowska, „Barochius Adeodatus”, w: Encyklopedia muzyczna PWM, red. Elżbieta Dziębowska, t. I, ab, Kraków 1979, s. 193.

I90 Anna i Zygmunt M. Szweykowscy, Wtosi w kapeli królewskiej polskich Wazów, Kraków I997, s. II9, I2I.

I9I B. Przybyszewska-Jarmińska, Muzyczne dwory, s. I54 (także tutaj występuje "urobione” włoskie nazwisko muzyka - w wersji „Barochio” lub „Barocchio”, oraz imiona „Deodato” lub „Theodato”).

I92 Wn akc. 6385, k. 94, I03, I08, I33, I35v; Kan 29/50I/38, s. I52, I58. 
nawet w wypadku zakonu augustianów, imię oraz wzmiankowaną informację pochodzącą z aktu z I640 r., znanego obecnie wyłącznie dzięki dziewiętnastowiecznej publikacji Łukaszewicza, w którym mowa o „Barockim”, augustianinie z klasztoru św. Marcina i równocześnie muzyku królewskim, utożsamienie Adeodatusa Perusinusa z Adeodatusem Barochiusem wydaje się uprawnione, przy czym „Perusinus” nie stanowi nazwiska, ale wskazanie miejsca pochodzenia: „z Perugii”' ${ }^{93}$. Nie kłóci się to ze wzmianką o augustianinie-śpiewaku (basie), z wszelką pewnością Barochiusie, zawartą w Gościńcu Adama Jarzębskiego, w którym czytamy w ustępie zatytułowanym Musica abo capella Króla J.M.:

W Kapelli Augustyanin /

Basista w kunszcie Rzymianin ${ }^{194}$.

W cytowanym tu siedemnastowiecznym wydaniu dziełka interpunkcja stosowana jest bardzo oszczędnie, w szczególności, jeżeli chodzi o przecinki. Zostały one wprowadzone w dwóch edycjach z XX w., w przypadku przytoczonego dwuwiersza w różnych miejscach, co skutkuje odmiennością jego znaczeń. W wydaniu Korotyńskiego mamy:

W kapelli augustyjanin,

Basista, w kunszcie Rzymianin ${ }^{195}$.

A u Tomkiewicza:

W kapelli augustyjanin

Basista w kunszcie, Rzymianin ${ }^{196}$.

W moim przekonaniu trafna jest wskazana interpunkcją interpretacja Korotyńskiego, a augustianinem, śpiewającym basem na sposób rzymski, był pochodzący z Perugii o. Adeodatus Barochius. Jako Włocha wzmiankowano go jeszcze w innych pomijanych dotąd w publikacjach źródłach. Najwcześniejsze dotyczy pierwszych miesięcy I638 r., kiedy Adeodatus Perusinus, włoski muzyk królewski, ułatwił augustianom lubelskim dostęp do Władysława IV, w wyniku czego otrzymali oni potwierdzenie własności darowanego im placu, na którym chcieli zbudować kościół ${ }^{197}$. Inne jest związane z powołanym w kościele św. Marcina bractwem św. Cecylii, które gromadziło warszawskich

I93 Niewątpliwym nadużyciem ze strony Grzegorza Utha, który korzystał z akt kapituły prowincji z I646 r., gdzie o. Adeodatus został określony jako „Perusinus”, jest posługiwanie się urobioną przez siebie „włoską" formą jego nazwiska - „Perusini”, zob.: G. Uth, Szkic historyczno-biograficzny, s. 26I.

194 A. Jarzębski, Gościniec, wyd. 1643, s. 30.

I95 Adama Jarzębskiego Gościniec, wyd. 1909, s. 27.

196 A. Jarzębski, Gościniec, wyd. 1974, s. 92.

$197 \mathrm{Kp} 2357$, k. Iv-2. Ks. Jan Ambroży Wadowski przytacza tę informację, wskazując na dokument królewski z 29 V I638 r., do którego powstania miał się przyczynić „przystęp” do Władysława IV dla lubelskich augustianów, „ułatwiony przez ich współbrata Adeodata Purusina [!], Włocha, S.T. Bakałarza, nadwornego muzyka królewskiego". 
muzyków, w tym królewskich, w szczególności w uroczystość patronki muzyków 2I listopada. Informacje na ten temat podaje Fulgenty Dryjacki w Horologium, lecz bardziej szczegółowe w swojej kronice Alipi Niedzielski, który powołuje się na Dryjackiego, ale wykorzystuje także znajdujący się jeszcze w początkach XIX w. w archiwum polskich augustianów „,rzymski dokument” w tej sprawie. Pisze on w odniesieniu do roku I646:

Bractwo muzyczne św. Cecylii w Warszawie. Podaje O. Dryjacki, że O. Walentyn [faktycznie Vincenzo Scapitta da Valenza - B.P.-J.], Włoch z zakonu franciszkanów konwentualnych, oraz Ojcowie Adeodat i Alfons augustianie, którzy trzej w kapeli królewskiej Władysława IV króla Polski byli śpiewakami, zatroszczyli się o bractwo św. Cecylii, Dziewicy i Męczenniczki, przy ołtarzu w kościele św. Marcina dla muzyków wraz z odpustami, a ponadto własnym kosztem corocznie odprawiali nabożeństwo: ołtarz marmurowy ozdabiali i dbali o to, ażeby wszystkie sprzęty liturgiczne były godne. Nabożeństwo to nie tylko wszyscy muzycy królewscy, lecz także Jego Królewska Miłość przykładnie współczcił swoją obecnością i pobożnością. W Archiwum jest przechowany rzymski dokument, ale współcześni [tj. żyjący w początkach XIX w. - B.P.-J.] muzycy rzadko zbierają się na nabożeństwie wotywnym w święto św. Cecylii, za to klasztor troszczy się o godność ołtarza ${ }^{198}$.

Dowiadujemy się zatem, że za powołaniem bractwa św. Cecylii stali trzej śpiewacy królewscy: augustianie Adeodat i Alfons (o którym niżej), jak również franciszkanin, skądinąd wiadomo, że także kompozytor, Vincenzo Scapitta da Valenza (z pewnością o nim była mowa w dokumencie wzmiankowanym, ale źle odczytanym przez Niedzielskiego). Z dotyczącej także i646 r. relacji Dryjackiego, który, być może dlatego, że sam był augustianinem, skoncentrował się na augustianach i pominął Scapittę, warto przytoczyć początkowy fragment, zawierający informację o tym, jakimi głosami śpiewali oo. Adeodat i Alfons:

W tym czasie w kościele św. Marcina ojców augustianów w Warszawie bractwo św. Cecylii zostało ufundowane i wprowadzone przez augustianów, którzy w kapeli króla Władysława IV byli włoskimi śpiewakami; [byli to] Wielebny O. Adeodat bas i Wielebny O. Alfons alt, którzy całą kapelę królewską w pewnych okresach, zwłaszcza w dniu św. Cecylii, sprowadzali ${ }^{199}$.

I98 Wibl 227, k. I79: „1646. Confraternitas S. C[a]eciliae Musicor[um] Varsaviae. Refert P. Dryacki, quia per P. Valentinum Ord[inis] S. Francisci Convent[ualis], Italum, et P[atres] Adeodatum ac Alphonsum Augustinianos, qui tres in Capella Regia Vladislai IV Regis Poloniae erant vocales musici, curaverunt Confraternitatem Sanctae C[a] eciliae V[irginis] et M[artyris] penes altare in templo S. Martini pro musicis cum indulgentiis, atq[ue] suis sumptibus hanc devotionem quotannis adimpleverunt: altare marmoreum ornabant et omnia suppellectilia, ut sint honesta, curabant. Quam devotio[nem] non tantum regii omnes musici, verum etiam et Sacra Regia Maiestas exemplariter cohonestabat sua praesentia ac devotione. In Archivio asservatur instrumentum Romanum, sed moderni musi[ci] rare congregantur pro votiva ad festum S. C[a]eciliae, sed Conventus de honestate altaris curat".

199 Kan 29/50I/23, s. I42: „Iisdem temporibus Confraternitas S. C[a]eciliae in ecclesia S. Martini Patrum Augustinianorum Varsoviae erat fundata et introducta per Augustinianos, qui in capella regis Vladislai IV fuerunt vocalistae Itali, R.P. Adeotatus basista et R.P. Alphonsus alcista, qui totam capellam regiam certis temporibus, eo magis pro die S. C[a]eciliae, conducebant". Zob. też: G. Uth, Szkic historyczno-biograficzny, s. 26I. 
Z wyżej cytowanych źródeł nie wynika, że bractwo św. Cecylii istniało dopiero od $\mathrm{I} 646 \mathrm{r} .{ }^{200}$, ale zapewne z tego czasu pochodził wspominany zaginiony dokument sporządzony w Rzymie, stanowiący, jak można domniemywać, albo zatwierdzenie bractwa, albo udzielenie jego członkom prawa do odpustów czy też innych przywilejów papieskich.

Kolejne informacje dotyczące Adeodata, ale i Alfonsa, są związane z ogłoszonymi w I65I r. obchodami w polskim Kościele rzymskokatolickim Wielkiego Jubileuszu ${ }^{201}$ (świętowanego w Rzymie w roku I650). Podczas Jubileuszu wierni, po spełnieniu określonych warunków, mogli uzyskać odpust. Niezbędna była w tym celu m.in. spowiedź, stąd w poszczególnych kościołach wyznaczano specjalnych spowiedników, biorąc pod uwagę także wiernych niewładających językiem polskim. Na spowiedników, jak podaje Dryjacki, wybrano m.in. augustianów „RR.PP. Adeodatum et Alphonsum capellae regiae praefectos [!]”, którzy mieli spowiadać Włochów ${ }^{202}$.

Obecnie znane źródła w istocie nie pozwalają na ustalenie, jak oryginalnie nazywał się bas działający w kapeli Władysława IV i Jana II Kazimierza o. Adeodatus Barochius, który zasłużywszy się dla klasztoru św. Marcina, w marcu I652 r., w czasie szalejącej zarazy, opuścił Warszawę i udał się w drogę powrotną do Italiii ${ }^{203}$. Jeżeli chodzi o imię, można je zreitalianizować do formy „Adeodato”. Z nazwiskiem problem jest większy. Występujące w pracach muzykologicznych wersje nazwiska „Barocchio” czy „Barochio” zostały przyjęte arbitralnie i bezpodstawnie. Można by wskazać inne, chyba bardziej prawdopodobne wersje, takie jak na przykład Barocci czy Barozzi. Dopóki nie znajdzie się źródło informujące o nazwisku muzyka we włoskim brzmieniu, najuczciwsze wydaje się jednak posługiwanie się znanym nazwiskiem zlatynizowanym - Barochius (jak wiemy, w piśmiennictwie muzykologicznym, nawet w przypadku znanego oryginalnego włoskiego nazwiska, powszechnie zlatynizowanym nazwiskiem Lilius określani są Vincenzo i Francesco Gigli).

Wśród wymienionych wyżej augustianów, którzy przyczynili się do powstania w kościele św. Marcina bractwa św. Cecylii oraz zostali wyznaczeni do spowiadania Włochów w czasie obchodów Wielkiego Jubileuszu w I65I r., był Pater Alphonsus, jak wiemy z tych źródeł, śpiewak (alt) w kapeli królewskiej Władysława IV co najmniej w I646 r., obecny też w Warszawie w I65I roku. Wobec faktu, że rachunki kapeli z czasów Władysława IV się nie zachowały, informacji o przynależności tego zakonnika-muzyka do zespołu nie da się nimi zweryfikować. Wiadomości przekazane

200 Niewykluczone, że faktycznie powstało ono już w I645 r., jak podano, bez odniesienia do źródła informacji, w: Warszawa: Stare Miasto: tekst, red. Jerzy Z. Łoziński i Andrzej Rottermund, opr. Zofia Baranowska i in., Warszawa 1993 (= Katalog zabytków sztuki w Polsce, seria nowa II/I), s. 2II.

20I Ogłoszenie jubileuszu w diecezji poznańskiej, z wyznaczeniem do jego obchodów czterech kościołów warszawskich, przez biskupa Kazimierza Floriana Czartoryskiego w piśmie z dnia 22 III I65I r., zob. Pa AE XXXVI, k. 26v-29v.

202 Kan 29/501/23, s. 197; zob. też: G. Uth, Szkic historyczno-biograficzny, s. 277.

203 Kan 29/5OI/23, s. I42; zob. też: ibid., s. 26I. 
przez Dryjackiego i Niedzielskiego uwiarygadniają natomiast akta kapituły prowincji polskiej z I646 r., w których w familii klasztoru św. Marcina znajduje się usytuowane obok imienia o. Adeodata z Perugii, a właściwie nawet razem z nim, imię i nazwisko o. Alfonsa: „PP. baccalaurei Adeodatus Perusinus, praesidens capituli, et Alphonsus Salvaticus"204 (akta te byly znane już Grzegorzowi Uthowi, który na ich podstawie napisał: „sprowadzono [do klasztoru św. Marcina - B.P.-J.] z Włoch Augustjanów artystów i wirtuozów, jak O. Adeodata Perusiniego [!] i O. Alfonsa Salmatrinę [!]”205). Co więcej, wydaje się uprawnione hipotetyczne datowanie początków jego muzycznej działalności na dworze królewskim na rok I645 lub nawet I644 (jako że starania o założenie i zatwierdzenie bractwa św. Cecylii, w których brał udział, musiały trwać już w tym czasie). Zapewne nie było go w kapeli w I643 r., a w każdym razie nie ma jego kanonu w wydanym w tym roku Cribrum musicum Scacchiego. W kontekście przytoczonej informacji, dotyczącej I65I r., wydaje się natomiast dziwne, że nie został on wymieniony w rachunkach kapeli Jana II Kazimierza z 1. I650-52. Tym samym jego przynależności do zespołu w tym właśnie czasie trudno byłoby obecnie dowieść.

Przytoczone wyżej informacje źródłowe w sposób znaczący zmieniają stan wiedzy o augustianinie-muzyku określanym w łacińskojęzycznych dokumentach jako Alphonsus Salvaticus lub Selvaticus, którego zidentyfikowałam jako Alfonso Selvaticiego, poświęcając mu uwagę w mojej wcześniejszej publikacji ${ }^{206} . \mathrm{Z}$ racji trudnej dostępności tego artykułu, wiele z zamieszonych w nim faktów i konstatacji tutaj powtórzę.

Nie wiadomo wprawdzie, kiedy Alfonso Selvatici opuścił Rzeczpospolitą, ale jest prawdopodobne, że dopiero w I655 r., w związku z najazdem szwedzkim, kiedy też ewakuował się dwór królewski. Okres „potopu” spędził zapewne w krajach Habsburgów austriackich. Niemal na pewno przez jakiś czas był muzykiem na dworze arcyksięcia Ferdynanda Karola w Innsbrucku - w tamtejszych źródłach jest wzmiankowany w I656 r. „P. Saluaticj”207 (Walter Senn, uznając „P.” za inicjał imienia, sugerował, że być może nazwisko zostało błędnie zapisane, a wpis mógł dotyczyć pochodzącego z Florencji muzyka nazwiskiem Pietro Salvetti; zdaniem Petera Királyego „P.” należy

204 Wn akc. 6385, k. I35v; por. Kan 29/50I/38, s. I58.

205 G. Uth, Szkic historyczno-biograficzny, s. 26I.

206 Najszerzej pisałam o nim w: Barbara Przybyszewska-Jarmińska, „Alfonso Selvatici. Zapomniany maestro di cappella Jana III Sobieskiego”, Diagonali 3/20I5 (czasopismo internetowe niedostępne obecnie online; wersja cyfrowa w Bibliotece Instytutu Sztuki PAN w Warszawie). Zob. też: Peter Király, „Musik und Musiker an der Residenz des Ferenc Nádasdy III”, w: Die Familie Nádasdy vom I6. bis ins 20. Jahrhundert. Tagungsband der 29. und 30. Schlaininger Gespräche 2009/2010, red. Rudolf Krope, Eisenstadt 2015 (= Wissenschaftliche Arbeiten aus dem Burgenland (WAB) I54), s. 175-197, zwłaszcza s. I84; tegoż: „Alfonso Selvatici - egy szerzetes-zenész Nádasdy Ferenc rezidenciáján és a lengyel királyi udvarban”, Lymbus 2017, s. 257-264 (Peter Király udzielił mi swoich artykułów przed drukiem, za co, jak również za inspirującą korespondencję i wymianę informacji, jestem mu serdecznie wdzięczna); Barbara Przybyszewska-Jarmińska, „The Reception of Music Composed in the Commonwealth of Poland and Lithuania in the I7th Century in the Countries to the South", w: The Musical Sources of Spis / Zips and Central Europe, red. Janka Petőczová, Bratislava 20I8, s. 42.

207 Zob.: Walter Senn, Musik und Theater am Hof zu Innsbruck, Innsbruck 1954, s. 247. 
traktować jako skrót od „Pater” $\left.{ }^{208}\right)$. Następnie, być może jeszcze w końcu lat pięćdziesiątych lub na początku sześćdziesiątych XVII w., znalazł się na dworze Ferenca Nádasdyego, węgierskiego magnata, mającego wówczas swoją główną siedzibę w Seibersdorf, a od drugiej połowy lat sześćdziesiatych w Pottendorf (obie miejscowości w Dolnej Austrii, niedaleko Baden). Nádasdy został stracony 30 IV I67I r. z wyroku sądu cesarskiego za udział w związanym z ruchami niepodległościowymi Węgrów tzw. spisku Wesselényego. Przed śmiercią magnata został sporządzony spis jego wierzycieli, w którym wymieniono m.in. sumę pieniędzy należną Selvaticiemu, wówczas (w I67I r.) już muzykowi królowej Polski Eleonory Marii, żony Michała Korybuta Wiśniowieckiego: „Alfonso Selvafici Musicus bey̌ der Königin in Pohlen, wegenn rückständigen Salarÿ 300 fl.”209. W istocie na służbę królów Polski Selvatici powrócił znacznie wcześniej, na pewno jeszcze za panowania Jana II Kazimierza, który 2I III I667 r. pisał do kardynała protektora Polski Virginio Orsiniego w Rzymie z prośbą o poparcie u papieża starań Selvaticiego o uzyskanie tytułu magistra teologii ${ }^{210}$. Sprawa miała dalszy ciąg już za panowania Michała Korybuta Wiśniowieckiego i zakończyła się sukcesem. Zachował się list króla do kardynała Orsiniego z II VI I670 r., stanowiący rekomendację dla Selvaticiego, włączony, wraz z dokumentem zwanym memoriale ( 3 września tego roku), o którym niżej, do akt postępowania kurii rzymskiej, zakończonego wydaniem przez papieża KlemensaX datowanego na I7 IX I670 r. breve. Ten ostatni dokument jest $\mathrm{w}$ istocie udzielonym przeorowi generalnemu zgromadzenia augustianów Girolamo Valvassoriemu pełnomocnictwem do nadania Selvaticiemu stopnia magistra, po zdaniu przez niego niezbędnego egzaminu ${ }^{2 I I}$. Najwyraźniej informacja o tej decyzji papieża dość długo nie docierała do Rzeczpospolitej, bowiem jeszcze w I67I r., ciaggle w sprawie magisterium z teologii dla o. Alfonsa, pisał do Rzymu z Warszawy (2I stycznia) dawny wazowski śpiewak, a następnie kanonik warmiński Lodovico Fantoni oraz z Lublina (30 sierpnia) król Michał Korybut Wiśniowiecki. Obaj polecali sprawę kardynałowi Orsiniemu, prosząc o jej poparcie u papieża ${ }^{212}$. Dopiero jesienią I67I r. o sukcesie starań dowiedział się sam zainteresowany. W liście pisanym z Warszawy, z is października tego roku, do Orsiniego podziękował mu za tytuł, a w kolejnym, też z Warszawy, z 8 VI I672 r., poinformował kardynała, że wysłał pieniądze należne za breve oraz prosił o pomoc w uzyskaniu

208 W. Senn, Musik und Theater, s. 247-248; P. Király, „Musik und Musiker”, s. I84; tegoż, „Alfonso Selvatici”, s. 259.

209 P. Király, „Musik und Musiker”, s. 184; tegoż, „Alfonso Selvatici”, s. 257.

210 Repertorium rerum Polonicarum ex Archivo Orsini in Archivo Capitolino Romae, I pars, collegit Wanda Wyhowska De Andreis, Romae I96I (= Elementa ad fontium editiones III), s. $58 \mathrm{nr} 532$. Jak wiemy z akt kapituły prowincji polskiej augustianów z 1646 r. (zob. przyp. 204), Selvatici był wówczas bakałarzem teologii.

2II Rasv, Sec. Brev., Reg., vol. I502, k. 54I-546v.

212 Repertorium rerum Polonicarum ex Archivo Orsini in Archivo Capitolino, II pars, collegit Wanda Wyhowska De Andreis, Romae 1962 (= Elementa ad fontium editiones VII), s. $170 \mathrm{nr}$ 935; Repertorium rerum Polonicarum, I pars, s. $70 \mathrm{nr} 65 \mathrm{I}$. 
i ekspedycji dokumentu ${ }^{213}$. Te listy są szczególnie ważne, ponieważ pozwalają ustalić wersję nazwiska używaną przez samego augustianina-muzyka - „Selvatici” (nazwisko to w różnych znanych i w części cytowanych tu źródłach występuje też w wariantach „Selvatico”, „Salvatico” i „Salvatici”, jeżeli pominiemy wersje łacińskie oraz te zniekształcone z dokumentów proweniencji austriackiej i węgierskiej).

W żadnym z wymienionych listów wysłanych z Polski za czasów Jana II Kazimierza Wazy oraz Michała Korybuta Wiśniowieckiego nie wspomina się o tym, że o. Alfonso Selvatici był muzykiem, w żadnym też nie ma informacji biograficznych wykraczających poza to, że był augustiańskim zakonnikiem. Bardziej instruktywne pod tym względem jest wzmiankowane breve Klemensa X skierowane do generała Girolama Valvassoriego ${ }^{214}$. Dowiadujemy się z niego, że Alfonso Selvatici, augustianin, pochodził z Bolonii, miał w I670 r. ponad 6o lat, więc urodził się przed I6ıo r., oraz że w I670 r. był w służbie króla Polski (Michała Korybuta Wiśniowieckiego), co wiemy też skądinąd. Informacje te znajdują się także w wytworzonym w kancelarii papieskiej włoskojęzycznym memoriale, w którym wspomniano także, że Selvataci miał w swojej biografii okres, w którym służył na dworach władców niemieckich („in servitii apprestati a diversi principi di Germania") ${ }^{215}$.

W świetle dotychczasowej, inna rzecz, że bardzo źle udokumentowanej źródłowo, wiedzy o kapeli królów Polski w XVII w. po „potopie”, zaskakującą wiadomość przynosi wpis w Tabula censuum klasztoru św. Marcina, w oryginale dokonany częściowo po łacinie, a częściowo po polsku, zatytułowany „R[everendus] $\mathrm{P}$ [ater] M[agister] Alphonsus":

Roku Pańskiego I678 w kwietniu po śmierci Wielce Czcigodnego Ojca Magistra Alfonsa Salvaticiego, Włocha, kapelmistrza Jego Królewskiego Majestatu, za suknie fl. 44. Ten ojciec płacił od stołu i mieszkania ${ }^{216}$.

Z zapisu wynika, że o. Alfonso Salvatici (czy, jak sam pisał, Selvatici) zmarł w I678 r., w kwietniu lub niewiele wcześniej. W każdym razie w tym miesiącu (w kwietniu) uzyskano 44 zł, być może ze sprzedaży jego ubrań. Dwie inne podane tu informacje

213 Repertorium rerum Polonicarum, II pars, s. 183 nr 995, s. $198 \mathrm{nr} 1072$.

$2 \mathrm{I} 4$ Bullarium Ordinis Sancti Augustini. Regesta, vol. VIII, I660-I700, wyd. Carolus Alonso, Romae 2003, nr 192, s. 75: „Hieronymo Valvassorio, priori generali Ordinis Eremitarum Sancti Augustini. Eidem concedit, ut fratrem Alphonsum Salvatico, Bononiensem, eiusdem Ordinis, in aetate 60 annorum et ultra et in servitium regis Poloniae constitutum, promoveat ad magisterii gradum in sacra theologia. Datum Romae, apud Sanctam Mariam Maiorem, die I7 Septembris [1670], anno [primo]". Wydawca regestu, odsyłając do źródła datowanego I7 IX I670 r., w pierwszym roku pontyfikatu Klemensa X, z nieznanych powodów zmienił rok kalendarzowy na $1672 \mathrm{i}$ w związku z tym skorygował rok pontyfikatu na trzeci. Oryginalna datacja źródła rękopiśmiennego została tu przywrócona.

2I5 Rasv, Sec. Brev., Reg., vol. I5O2, k. 542.

216 Wmhw A/I/326I, k. 65v: „Anno D[omi]ni 1678 in Aprili post mortem A[dmodum] R[everendi] P[atris] M[agistri] Alphonsi Salvatici, Itali, magistri capellae S[acrae] R[egiae] M[aiestatis], za suknie fl. 44. D[ic]tus p[ate]r płacił od stołu i mieszkania" (wpis dokonany w I682 r.). 
wymagają osobnego omówienia: zapłata dokonywana przez Selvaticiego w klasztorze za jedzenie i mieszkanie, jak również sprawowanie przez niego funkcji kapelmistrza królewskiego.

Wydawałoby się, że, będąc augustianinem, Alfonso Selvatici, kiedy przebywał w Warszawie, powinien, tak jak inni zakonnicy, mieć mieszkanie i utrzymanie w klasztorze św. Marcina. Tak zapewne było w I646 r., kiedy został w aktach kapituły prowincji wymieniony wraz z Adeodato Barochiusem w społeczności tego konwen$\mathrm{tu}^{217}$. Trzeba jednak zauważyć, że, choć jest niemal pewne, iż pozostawał w Warszawie także w kolejnych latach, co najmniej do roku I65I, w zachowanych relacjach z obrad kapituł z tego czasu nie był wymieniany, podobnie jak Barochius, wśród zakonników klasztoru św. Marcina (nie wymieniono go też w roku I655 i I660) ${ }^{218}$. Niestety w szeregu zachowanych źródeł, dotyczących przebiegu kapituł z okresu po I660 r., familie klasztorów nie są podawane ${ }^{219}$. Tak też jest w przypadku kapituły prowincji, jaka odbywała się w Lublinie w październiku 1667 r., w której udział Selvaticiego jest pewny, ponieważ wystąpił tam jako praesidens ${ }^{220}$. W aktach kapituły z I673 r., w których podano zakonników przebywających w poszczególnych klasztorach, nie został odnotowany ${ }^{221}$.

Fakt, że w aktach kapituł prowincji Selvatici na ogół (z co najmniej jednym wyjątkiem, potwierdzonym w roku 1646) nie był „przyporządkowywany” do warszawskiego klasztoru augustianów ani żadnego innego, wydaje się nieprzypadkowy. Wynikało to zapewne $\mathrm{z}$ jego specjalnego traktowania $\mathrm{w}$ konwencie $\mathrm{w}$ związku z pełnionymi obowiązkami w kapeli królewskiej. Wskazuje na to przykład innego augustianina zaangażowanego w prace na rzecz króla (wówczas Władysława IV), którego przypadek był omawiany na kapitule w 1637 r.:

[na marginesie] O Ojcu Agostino Włochu.

[w tekście podstawowym] Wielebny Ojciec Magister Agostino Cesenas, Włoch, który pełni posługę w kaplicy królewskieje22, wyznaczony jest ze społeczności zakonnej klasztoru warszawskiego; we wszystkich sprawach, w jakich inni są podlegli przełożonym, poddany jest zwierzchnictwu przeora klasztoru, i - z wyjątkiem posług w kaplicy - żeby nigdy nie wychodził z klasztoru bez zezwolenia, powinien jednak zwracać klasztorowi koszty utrzymania ${ }^{223}$.

217 Por. przyp. 204.

218 Żadnego z tych dwóch augustianów-muzyków nie ma wśród wymienionych warszawskich zakonników w aktach kapituł z l. I649, I65I, I655 i 1660, zob. Wn akc. 6385, k. I47v, I57, I72, I80.

219 Tak jest w aktach kapituł z l. I664, I667, I670 i I676.

$220 \mathrm{Wn}$ akc. 6385, k. 192, I93v, 430.

22I Ibid., k. 202v.

222 Zapis nie pozwala jednoznacznie stwierdzić, czy chodzi o kaplicę czy kapelę.

$223 \mathrm{Kan}$ 29/5OI/38, s. I25-I26: „De P[at]re Augustino Italo” (marginalium); „V[e]n[er]abilis P[ate]r $\mathrm{M}[\mathrm{a}] \mathrm{g}[$ iste]r $\mathrm{r}$ Augustinus Cesenas, Italus, qui est a servitiis capellae S.R.M[aies]t[a]tis, de familia con[ven]tus Varsovien[sis] collocatur; in omnibus, [126] in quibus alii superioribus sunt subiecti, prioris [!] con[ven] tus subicitur, nec unquam sine licentia praeter servitia capellae e conventu egrediatur, contentationem nihilominus pro victu conventui dare debet". 
Jako że w aktach kapituł z I637 r. nie zachował się skład familii konwentu św. Marcina, nie można stwierdzić, czy z uwagi na fakt, że bliżej nieznany o. Agostino Cesenas (czy może raczej da Cesena?), podobnie jak o. Alfonso Selvatici, musiał płacić za utrzymanie w klasztorze, był zaliczany do grona zakonników tego klasztoru, czy też nie.

Historycy muzyki przyjmują, że od I657 lub od ok. I657 r. zespołami kolejnych królów Polski, czyli Jana II Kazimierza Wazy, Michała Korybuta Wiśniowieckiego, Jana III Sobieskiego i Augusta II Wettina (w tym ostatnim przypadku dzieląc się obowiązkami z Johannem Christophem Schmidtem), kierował do śmierci, w I703 lub 1704 r., Jacek Różycki ${ }^{224}$. Biogram muzyka jest jednak bardzo słabo udokumentowany, do tego stopnia, że w istocie nie można stwierdzić, od kiedy był on kapelmistrzem ani czy piastował to stanowisko przez cały podany okres. Wobec bardzo nielicznych odnalezionych źródeł z drugiej połowy XVII w., odnoszących się do kapeli królewskiej, działalność kapelmistrzowską Różyckiego w poszczególnych latach potwierdzają przede wszystkim informacje pochodzące z akt metrykalnych warszawskich kościołów, a zwłaszcza parafii św. Jana Chrzciciela. W źródłach tych jest odnotowany cały szereg przypadków, kiedy muzyk występował jako ojciec, ojciec chrzestny lub świadek ślubu, a obok jego nazwiska umieszczono w zapisach metrykalnych informację o pełnionej funkcji - „magister capellae S.R.M.” (stanowisko męża jest także podawane w tych wpisach przy imieniu i nazwisku drugiej żony muzyka, Marianny). Jeżeli chodzi o 1. 1667-78, a więc potwierdzony drugi etap pobytu Selvaticiego w Rzeczypospolitej, istnieją przekazy źródłowe (metrykalne) informujące, że w okresie od października 1670 do października I676 r. kapelmistrzem królewskim był na pewno Różycki, a kolejny zapis stanowiący takie upewnienie pochodzi z kwietnia $1680 \mathrm{r}^{225}$. Można by więc brać pod uwagę ewentualność, że Selvatici został powołany na to stanowisko u schyłku i676 lub w 1677 r. przez Jana III Sobieskiego. Zajmowałby je zatem krótko, bo zapewne około kilkunastu miesięcy, jakie pozostały mu do śmierci. Istnieje też możliwość, że w Tabula censuum podano funkcję Selvaticiego, jaką pełnił w przeszłości, jeszcze w latach sześćdziesiątych XVII wieku. W tym czasie kapelmistrzostwo Różyckiego potwierdzone jest jedynie informacjami z księgi chrztów parafii św. Jana Chrzciciela,

224 A. Chybiński, Stownik, s. Io8; Stownik muzyków polskich, t. 2, s. I52; A. Patalas, „Różycki Jacek”, s. 496; B. Przybyszewska-Jarmińska, Muzyczne dwory, s. 207.

225 Barbara Przybyszewska-Jarmińska, „Muzyka i finanse. II”, Muzyka 44 (I999) nr 3, s. 91. Zob. też Wa Par. św. Jana I09, s. I07: I2 X I670 r.: ojcem chrzestnym był "Jacinthus Ruzycki, S.R.M. capellae magister”) i s. 473: 28 X I676 r.: matką chrzestną została „G[e]n[er]osa Marianna Rozycka G[e]n[er]osi Hyacinthi Rozycki, magistri capellae S.R.M., legitima consors” oraz Wa Par. św. Jana 304, s. I24: 22 IV I680 r. odbył się ślub, w którym funkcję jednego ze świadków powierzono „G[e]n[er]oso D[omi]no Hyacintho Rozycki, S.R.M. capellae magistro”. W okresie pomiędzy 28 X 1676 r. a 22 IV I680 r. nie ma w aktach metrykalnych parafii św. Jana Chrzciciela zapisów odnoszących się do Jacka Różyckiego. Nie są też znane inne źródła, które potwierdzałyby, że w tym czasie Różycki pozostawał królewskim kapelmistrzem. 
odnoszącymi się do 4 IX I662 i I4 II I663 r. ${ }^{226}$. W kolejnych, nielicznych w tych latach, wpisach, w których wymieniany jest Różycki, jego zawód i funkcja nie występują lub, co uderzające, jest on określony jako muzyk królewski, bez wskazania jego stanowiska w kapeli (8 VIII I667 r.) ${ }^{227}$. W świetle tych, jedynych obecnie znanych, źródeł nie można mieć pewności, że to Różycki był kapelmistrzem w zespole muzycznym Jana II Kazimierza w ostatnich latach przed abdykacją króla. Niewykluczone więc, że kapelą kierował wówczas Selvatici. Wreszcie, istnieje możliwość, że funkcja kapelmistrza była dzielona pomiędzy różne osoby, na przykład z uwagi na rodzaj wykonywanej muzyki. W każdej ewentualności wątpliwości wiążą się z faktem, że nie są znane żadne kompozycje muzyczne Selvaticiego ani jakiekolwiek informacje o tym, że niegdyś takie istniały. Ponieważ w dziejach kapeli królów Polski w XVII w. powierzenie kierownictwa zespołu osobie niemającej dorobku kompozytorskiego byłoby ewenementem, odnalezienie chociaż śladów twórczości muzycznej o. Alfonsa miałoby szczególne znaczenie dla uprawdopodobnienia jego wskazanej w Tabula censuum funkcji. Poszukiwania trwaja.

\section{BIBLIOGRAFIA}

Bartoszewicz, Julian. Kościoty warszawskie rzymsko-katolickie opisane pod względem historycznym. Warszawa: S. Orgelbrand, I855.

Bullarium Ordinis Sancti Augustini. Regesta. Wyd. Carolus Alonso. T. 8, I669-I700. Romae: Romae Inst. Historicum Augustinianum, 2003.

Chybiński, Adolf. Stownik muzyków dawnej Polski do roku I80o. Kraków: PWM, [1949].

Chybiński, Adolf. „Z dziejów muzyki polskiej do I80o roku”. Muzyka 4, nr 7-9 [specjalny pt. Muzyka polska] (1927): 3I-72.

Diariusz podróży do Polski wydany z pamiętników Jana Chrzciciela Faggiuoli. Wyd. Władysław Kulczycki. Czas. Dodatek Miesięczny, 3 (I858) t. II: 237-306.

Dobrzańska-Fabiańska, Zofia. „Pękiel Bartłomiej”. W: Encyklopedia Muzyczna PWM, red. Elżbieta Dziębowska. T. 8, 83-87. Kraków: PWM 2004.

Dobrzańska-Fabiańska, Zofia. „Wstęp”. W: Bartłomiej Pękiel, Opera omnia. T. I, Utwory wokalno-instrumentalne. Wyd. Zofia Dobrzańska-Fabiańska. Kraków: Musica Iagellonica, 1994 (= Monumenta Musicae in Polonia, seria A: Opera omnia).

Eitner, Robert. Biographisch-Bibliographisches Quellen-Lexikon der Musiker und Musikgelehrten. T. I. Leipzig: Breitkopf \& Haertel, 1900, przedruk Graz: Akademische Druck-u. Verlagsanstalt, 1959.

226 Wa Par. św. Jana Io8, s. 74: 4 IX I662 r.: „Hiacinthus Rozicki, magister capellae S.R.M.” (wpis, jako najwcześniejszy potwierdzający kapelmistrzostwo Różyckiego, wskazał Hieronim Feicht, zob.: tegoż, „Kompozycje religijne Bartłomieja Pękiela”, w: tegoż, Studia, s. 3I2); s. 84: I4 II I663 r.: „Spectabilis Hiacynthus Ruzycki, S.R.M. capellae mag[iste] r".

227 Wa Par. św. Jana 108, s. 256: 8 VIII I667 r.: „Dominus Hiacynthus Rozycki, S.R.M. musicus”. 
Feicht, Hieronim. „Kompozycje religijne Bartłomieja Pękiela”. Maszynopis, Lwów 1925.

Feicht, Hieronim. „Muzyka w okresie polskiego baroku”. W: Z dziejów polskiej kultury muzycznej. T. I, red. Zygmunt M. Szweykowski. Kraków: PWM, I958.

Feicht, Hieronim. „Przyczynki do dziejów kapeli królewskiej w Warszawie za rządów kapelmistrzowskich Marka Scacchiego". Kwartalnik Muzyczny I, nr 2 (I929): I25-I44.

Feicht, Hieronim. Studia nad muzyka polskiego renesansu i baroku. Kraków: PWM, I980.

Gołos, Jerzy. Warszawskie organy: historia i zabytki. T. 2, Katalog aktualny, katalog historyczny. Warszawa: Fundacja Artibus, 2003.

Jachimecki, Zdzisław. Historia muzyki polskiej (w zarysie). Warszawa-Lublin: Gebethner i Wolff, I920.

Jachimecki, Zdzisław. „Kontrapunkciści polscy w kapeli Władysława IV”. Mtoda Muzyka 2, nr I9 (1909): 3-5.

Jachimecki Zdzisław. Muzyka polska w rozwoju historycznym od czasów najdawniejszych do doby obecnej. T. I, Od Bogurdzicy do Chopina wtącznie. Kraków: Księgarnia Stefana Kamińskiego, 1948.

Jachimecki, Zdzisław. Rozwój kultury muzycznej w Polsce. Kraków: Ant. Piwarski i Sp., I9I4.

[Jarzębski, Adam] Adama Jarzębskiego Gościniec abo Opisanie Warszawy I643 r. Wyd. Władysław Korotyński. Warszawa: Wydawnictwo Towarzystwa Opieki nad Zabytkami Przeszłości, 1909

Jarzębski, Adam. Gościniec abo Krotkie opisanie Warszawy. Opr. i wstęp Władysław Tomkiewicz. Warszawa: PWN, 1974.

Joannes Baptista Lancelotti (I622-I627). Wyd. Tadeusz Fitych. Kraków: PAU, Fundacja Lanckorońskich, 200I (= Acta Nuntiaturae Polonae 22/I).

Király, Peter. „Alfonso Selvatici - egy szerzetes- zenész Nádasdy Ferenc rezidenciáján és a lengyel királyi udvarban”, Lymbus 20I7: 257-264.

Király, Peter. „Musik und Musiker an der Residenz des Ferenc Nádasdy III”. W: Die Familie Nádasdy vom I6. Bis ins 20 Jahrhundert. Tagungsband der 29. und 30. Schlaininger Gespräche 2009/2010, red. Rudolf Krope, 175-197. Eisenstadt: Landesmuseum Burgenland 2015 (= Wissenschaftliche Arbeiten aus dem Burgenland (WAB) I54).

Kmicic-Mieleszyński, Wacław. „Geneza Cribrum musicum”. Muzyka 2, nr 3 (1957): 3-17.

Kobierzycki, Stanisław. Historia Wtadystawa, królewicza polskiego i szwedzkiego. Wyd. Janusz Byliński i Włodzimierz Kaczorowski, przekł. Marek Krajewski. Wrocław: Wydawnictwo Uniwersytetu Wrocławskiego, 2005.

Kolak, Wacław. Katalog Archiwum OO. Augustianów I299-1950. Kraków: Klasztor OO. Augustianów w Krakowie, Archiwum Państwowe w Krakowie, 1996.

Kowalczyk, Janina. „Augustianie-Eremici”, III: „W Polsce”. W: Encyklopedia Katolicka. T. I, red. Feliks Gryglewicz, Romuald Łukaszyk, Zygmunt Sułowski. Lublin: Towarzystwo Naukowe KUL, I985.

Kratochwil, Zofia. „Augustianie w Warszawie. Kościół i klasztor św. Marcina (I356-I864)”. Warszawskie Studia Teologiczne 7 (1994): 19I-2I6.

Łoziński, Jerzy Z., Andrzej Rottermund, red. Warszawa: Stare Miasto: tekst, opr. Zofia Baranowska i in. Warszawa: Wydawnictwa Artystyczne i Filmowe, 1993 (= Katalog Zabytków Sztuki w Polsce. Seria nowa II/I). 
Łukaszewicz, Józef. Krótki opis historyczny kościotów parochialnych [...] Diecezji Poznańskiej. T. 3. Poznań: Nakładem Księgarni Jana Konstantego Żupańskiego, I863.

Milan, Gabriella. „Fagiuoli Giovanni Battista”. W: Dizionario Biografico degli Italiani. T. 44, I75-I79. Roma: Treccani 1994.

Mizgalski, Jerzy. „Organiści i organmistrze polscy”. Prace Naukowe Instytutu Muzykologii UW I (I96I): 58-II3.

Niemcewicz, Julian Ursyn. Zbiór pamiętników o dawnej Polszcze. T. 3. Warszawa: N. Glücksberg, I822.

Niklewska, Jolanta. „Nowy nabytek Muzeum Historycznego M. St. Warszawy”. Rocznik Warszawski 28 (1998): 323-331.

Niklewska, Jolanta. „Tabula censuum warszawskiego kościoła Św. Marcina jako źródło poznania siedemnastowiecznych dochodów klasztoru". Almanach Muzealny 2 (1999): 85-100.

Patalas, Aleksandra. „Różycki Jacek”. W: Encyklopedia muzyczna PWM, red. Elżbieta Dziębowska T. 8, 496. Kraków: PWM, 2004.

Perz, Mirosław. „Pękiel Bartłomiej”. Grove Music Online, https://doi.org/Io.Io93/gmo/ 978I561592630.article.21208.

Poliński, Aleksander. „Mielczewski Marcin”. W: Wielka Encyklopedia Powszechna Ilustrowana, IO-II. Seria I, t. 47-48. Warszawa: Drukarnia „Gazety Handlowej”, I9I2.

Polska, jej dzieje i kultura. T. 2, I572-I795, opr. Jan Stanisław Bystroń i in. Warszawa: Księgarnia Trzaski, Everta i Michalskiego, [1929].

Przyboś, Adam. „Prażmowski Wojciech Remigian”. W: Polski Stownik Biograficzny, T. 28, 336. Wrocław i in.: Zakład Narodowy im. Ossolińskich, Wydawnictwo Polskiej Akademii Nauk, 1984-85.

Przybyszewska-Jarmińska, Barbara. „Alfonso Selvatici. Zapomniany maestro di cappella Jana III Sobieskiego". Diagonali 3 (2015) (czasopismo internetowe niedostępne obecnie online; wersja cyfrowa w Bibliotece Instytutu Sztuki PAN w Warszawie).

Przybyszewska-Jarmińska, Barbara. Barok. Cz. I, I595-1696. Warszawa: Sutkowski Edition, 2006 (= Historia Muzyki Polskiej 3).

Przybyszewska-Jarmińska, Barbara. Marcin Mielczewski and Music under the Patronage of the Polish Vasas. Przekł. John Comber. Frankfurt am Main: Peter Lang, 2014 (= Eastern European Studies in Musicology 3).

Przybyszewska-Jarmińska, Barbara. „Marcin Mielczewski - życie i dorobek”. W: Marcin Mielczewski. Studia, red. Zygmunt M. Szweykowski, 7-26. Kraków: Musica Iagellonica, I999.

Przybyszewska-Jarmińska, Barbara. Muzyczne dwory polskich Wazów. Warszawa: Wydawnictwo Naukowe Semper, 2007.

Przybyszewska-Jarmińska, Barbara. „Muzyka i finanse. Nieznane źródła do dziejów życia muzycznego na dworze królewskim polskich Wazów. II”. Muzyka 44, nr 3 (I999): 83-9I.

Przybyszewska-Jarmińska, Barbara. Muzyka pod patronatem polskich Wazów. Marcin Mielczewski. Warszawa: Instytut Sztuki PAN, 20II.

Przybyszewska-Jarmińska, Barbara. „The Reception of Music Composed in the Commonwealth of Poland and Lithuania in the I7th Century in the Countries to the South". W: The Musical Sources of Spiš / Zips and Central Europe, red. Janka Petőczová, 33-43. Bratislava: Ústav hudobnej vedy SAV, 2018. 
Przybyszewska-Jarmińska, Barbara. „Wstęp”. W: Asprilio Pacelli, Sacrae cantiones, wyd. Barbara Przybyszewska-Jarmińska. Warszawa: Instytut Sztuki PAN, Liber Pro Arte, 2012 (= Monumenta Musicae in Polonia, seria B: Collectanea musicae artis).

Repertorium rerum Polonicarum ex Archivo Orsini in Archivo Capitolino Romae. I pars, collegit Wanda Wyhowska De Andreis. Romae: Institutum Historicum Polonicum, 196I (= Elementa ad fontium editiones III).

Repertorium rerum Polonicarum ex Archivo Orsini in Archivo Capitolino. II pars, collegit Wanda Wyhowska De Andreis. Romae: Institutum Historicum Polonicum, I962 (= Elementa ad fontium editiones VII).

Rostirolla, Giancarlo. „Musicisti Umbri nella Cappella Giulia di San Pietro in Vaticano dalle origini agli inizi del Seicento. Con una nota sul magistero padovano di fra Rufino Cecchi Bartolucci di Assisi”. W: Arte e Musica in Umbria tra Cinquecento e Seicento. Atti del XII Convegno di Studi Umbri. Gubbio-Gualdo Tadino. 30 novembre-2 dicembre 1979, red. Biancamaria Brumana, Francesco F. Mancini, II5-I47. Gubbio: Centro di studi umbri, I98I.

Senn, Walter. Musik und Theater am Hof zu Innsbruck. Innsbruck: Österreichische Verlagsanstalt, 1954 .

Stownik muzyków polskich, red. Józef M. Chomiński. T. I-2. Kraków: PWM, 1964, 1967.

[Sobieszczański, Franciszek M.] Dzielnica Staromiejska w Warszawie. Szkice historyczno-obyczajowe Franciszka Maksymiljana Sobieszczańskiego. Zebrał Alexander Kraushar. Warszawa: Druk L. Bogusławskiego, [1920] (= Biblioteka Dzieł Wybornych).

Sołtan, Andrzej. „Muzycy warszawscy w latach 1583-1655”. Rocznik Warszawski I8 (1985): $23-59$.

Szweykowscy, Anna i Zygmunt M. Wtosi w kapeli królewskiej polskich Wazów. Kraków: Musica Iagellonica, 1997.

Szweykowska, Anna. „Barochius Adeodatus”. W: Encyklopedia Muzyczna PWM, red. Elżbieta Dziębowska. T. I, 193. Kraków: PWM, I979.

Szweykowska, Anna. „Kapela królewska Jana Kazimierza w latach I649-I652”. Muzyka I3, nr 4 (1968): 40-48.

Szweykowska, Anna. „Luparini Giuseppe”. W: Encyklopedia Muzyczna PWM, red. Elżbieta Dziębowska. T. 5, I48. Kraków: PWM, 1997.

Szweykowska, Anna. „Notatki dotyczące kapeli królewskiej w XVII wieku”. Muzyka I6, nr 3 (I97I): 9I-98.

Tabel' domam" g. Varšavy i predměst'â Pragi, [Varšava] 1887

Uth, Grzegorz. Szkic historyczno-biograficzny zakonu augustiańskiego w Polsce. Kraków: Nakładem OO. Augustianów w Krakowie, I930.

Wejnert, Aleksander. Starożytności Warszawy. Dzieto zbiorowe. T. 4. Warszawa: Bank Polski, I856.

Wejnert, Aleksander. Starożytności Warszawy. Dzieto zbiorowo-zeszytowe. T. I. Warszawa: Józef Unger, I848.

Zieliński, Jarosław. Atlas dawnej architektury ulic i placów Warszawy. T. II, Miechowska-Myśliwiecka. Warszawa: TONZ, 2005 (= Biblioteka Towarzystwa Opieki nad Zabytkami).

Źródta do dziejów Warszawy. Rejestry podatkowe i taryfy nieruchomości I5I0-I770. Wyd. Anna Berdecka, Janina Rutkowska, Anna Sucheni-Grabowska, Hanna Szwankowska. Warszawa: PWN, I963. 
INFORMATION FROM AUGUSTINIAN SOURCES CONCERNING I7TH-CENTURY MUSIC LIFE IN WARSAW'S CHURCH OF ST MARTIN AS WELL AS ROYAL MUSICIANS FROM THAT PERIOD

From the 17th-century onward, when Warsaw's Royal Castle became the main seat of the successive Polish kings, the Augustinian Church of St Martin was not only the venue for the relatively intensive music activity of the Augustin Friars themselves and of musicians whom they hired, but also for performances by the royal ensemble. The royal musicians who belonged to the Order of Saint Augustine were lodged in the monastery itself. Despite enormous losses related to the 1864 dissolution of the monastery following the January Uprising, some of the handwritten materials concerning its history, as well as the documents of the Polish Augustinian province, have been preserved (though dispersed) and may provide musicologists with hitherto unresearched, precious sources of knowledge on this subject. The first section of the paper is dedicated to music and musicians in St Martin's Church, the organ and its renovations, as well as that church's organists known by name (who included: Izajasz of Bochnia, Wilhelm Ruczkowski, Mikołaj Sieracki, Marian Chebdowski, and Hieronim Bobowski), cantors (Andreas Jaslav, Ambrosius Gruzelowicz, Marian Chebdowski, Hieronim Bobowski - who held the post of organist in the Kraków monastery, Bonawentura Krawarski, Chrysostomus Truszkowski, and Esaias Pawlikowicz (?)), as well as musicians-members of the monastic community who performed other functions (in their numbers, again Bonawentura Krawarski, as well as Andrzej Chrzanowski), and lay musicians employed by the friars. The surviving bills from the I680s and 9os allow us to reconstruct the occasions on which King John III Sobieski's ensemble frequently performed in this church, which also once hosted the ensemble of Cardinal Michał Stefan Radziejowski. In later sections I quote hitherto entirely unknown information from Augustinian manuscripts and other supplementary sources of various provenance, concerning the biographies of royal musicians. From these documents we learn of: Asprilio Pacelli's aborted plan of journey to Rome in I623; the whereabouts of a tenement house purchased by Marcin Mielczewski and his wife Jadwiga née Kołaczek; Bartłomiej Pękiel's links to the monastery of St Martin, and the year of his death (he died in I666, and not around I670, as it has been accepted so far); the period of the royal bass-singer Adeodato Barochius' (OESA) work in Warsaw and his origins (he came from Perugia), as well as of his founding, along with the Conventual Franciscan Vincenzo Scapitta da Valenza, and another Augustinian, Alfonso Selvatici, of the Fraternity of St Cecilia at St Martin's Church. Finally, we obtain information concerning the biography of that last musician, including his connection to the royal ensemble (where he sang alto), from the times of King Ladislaus IV Vasa, and subsequently after a break in the I650s (possibly also the early I66os) during the reigns of John II Casimir Vasa, Michael Korybut Wiśniowiecki, and John III Sobieski. According to a source from Warsaw's Augustinian monastery, Selvatici died in I678 as the royal Kapellmeister. 
Słowa kluczowe / keywords: historia muzyki w XVII w. / I7th-century music history, Warszawa / Warsaw, Augustianie / Augustinians, organiści / organists, kantorzy / cantors, kapela królów Polski / the Polish kings' ensemble

Dr hab. Barbara Przybyszewska-Jarmińska, muzykolog, profesor w Instytucie Sztuki PAN, redaktor naczelna serii Monumenta Musicae in Polonia. Jej badania dotyczą przede wszystkim historii muzyki w Rzeczypospolitej Obojga Narodów od schyłku XVI do początków XVIII w., migracji muzycznych oraz teorii edytorstwa muzyki dawnej. Jest m.in. autorką syntezy historii muzyki w Rzeczypospolitej w XVII w., monografii życia i twórczości Marcina Mielczewskiego oraz edycji utworów Luki Marenzia, Asprilia Pacellego, Marcina Mielczewskiego, Franciszka Liliusa, Marca Scacchiego i Kaspara Förstera jun.

barbara.przybyszewska-jarminska@ispan.pl

\title{
Nowość wydawnicza Instytutu Sztuki PAN
}

\author{
Katarzyna Korpanty \\ Niemiecka nauka kompozycji \\ w XVII i na początku wieku XVIII
}

iswydawnictwo@ispan.pl

\section{Drugi tom serii „Muzyka polska za granicą”}

Między Warszawą a Paryżem (1918-1939)

red. Beata Bolestawska-Lewandowska i Jolanta Gusy-Pasiak

iswydawnictwo@ispan.pl 